\title{
A Review of Romiplostim Mechanism of Action and Clinical Applicability
}

\author{
James B Bussel $\mathbb{D}^{\prime}$ \\ Gerald Soff $^{2}$ \\ Adriana Balduzzi ${ }^{3}$ \\ Nichola Cooper ${ }^{4}$ \\ Tatiana Lawrence ${ }^{5}$ \\ John W Semple 6 ,7
}

'Department of Pediatrics, Division of Hematology, Weill Cornell Medicine, New York, NY, USA; ${ }^{2}$ Department of Medicine, Hematology Service, Memorial Sloan-Kettering Cancer Center,

New York, NY, USA; ${ }^{3}$ Clinica Pediatrica Università degli Studi di Milano Bicocca, Ospedale San Gerardo, Monza, Italy; ${ }^{4}$ Hammersmith Hospital, Imperial College, London, UK; ${ }^{5}$ Amgen Inc., Thousand Oaks, CA, USA; ${ }^{6}$ Division of Hematology and Transfusion Medicine, Lund University, Lund, Sweden;

${ }^{7}$ Department of Pharmacology, University of Toronto, Toronto, ON, Canada
Correspondence: James B Bussel Department of Pediatrics, Division of Hematology, Weill Cornell Medicine, 525 East 68th St, P695, New York, NY, I0065, USA

Tel $+|9| 729|509|$

Fax +12127468609

Email jbussel@med.cornell.edu

\begin{abstract}
Thrombocytopenia results from a variety of conditions, including radiation, chemotherapy, autoimmune disease, bone marrow disorders, pathologic conditions associated with surgical procedures, hematopoietic stem cell transplant (HSCT), and hematologic disorders associated with severe aplastic anemia. Immune thrombocytopenia (ITP) is caused by immune reactions that accelerate destruction and reduce production of platelets. Thrombopoietin (TPO) is a critical component of platelet production pathways, and TPO receptor agonists (TPO-RAs) are important for the management of ITP by increasing platelet production and reducing the need for other treatments. Romiplostim is a TPO-RA approved for use in patients with ITP in the United States, European Union, Australia, and several countries in Africa and Asia, as well as for use in patients with refractory aplastic anemia in Japan and Korea. Romiplostim binds to and activates the TPO receptor on megakaryocyte precursors, thus promoting cell proliferation and viability, resulting in increased platelet production. Through this mechanism, romiplostim reduces the need for other treatments and decreases bleeding events in patients with thrombocytopenia. In addition to its efficacy in ITP, studies have shown that romiplostim is effective in improving platelet counts in various settings, thereby highlighting the versatility of romiplostim. The efficacy of romiplostim in such disorders is currently under investigation. Here, we review the structure, mechanism, pharmacokinetics, and pharmacodynamics of romiplostim. We also summarize the clinical evidence supporting its use in ITP and other disorders that involve thrombocytopenia, including chemotherapy-induced thrombocytopenia, aplastic anemia, acute radiation syndrome, perisurgical thrombocytopenia, post-HSCT thrombocytopenia, and liver disease.
\end{abstract}

Keywords: immune thrombocytopenia, pharmacokinetics, pharmacodynamics, structure, thrombopoietin receptor agonist

\section{Introduction}

Thrombocytopenia can occur because of a variety of conditions, including autoimmune disease, bone marrow disorders, hematologic disorders associated with severe aplastic anemia, chemotherapy, radiation, pathologic conditions associated with surgical procedures, and hematopoietic stem cell transplantation (HSCT). ${ }^{1}$ It is well known that thrombopoietin (TPO) plays a critical role in platelet production and other hematopoietic pathways. ${ }^{2}$ TPO receptor agonists (TPO-RAs) make an important contribution to the management of immune thrombocytopenia (ITP) by increasing platelet production and therefore reducing the need for other treatments or platelet transfusions. ${ }^{3}$ While the mechanism(s) of action of TPO-RAs center around increasing platelet production, these agents may play a larger role in the host. 
Development of early (first-generation) TPO-RAs (eg, PEGylated megakaryocyte growth and development factor) was eventually discontinued because of neutralizing antibodies that cross-reacted with endogenous TPO. ${ }^{4}$ As a result, the second-generation TPO-RAs, such as romiplostim, eltrombopag, and avatrombopag, were developed with the goal of avoiding these cross-reacting immune responses. ${ }^{4}$

Romiplostim is a TPO-RA that has been used in adults with chronic ITP for more than 11 years. Use of romiplostim was recently approved in pediatric patients in the United States and the European Union, and use in adults has been extended to include those with newly diagnosed ITP. ${ }^{5,6}$ The efficacy of romiplostim in severe aplastic anemia, chemotherapy-induced thrombocytopenia, and several other thrombocytopenic disorders is currently under investigation. ${ }^{1}$ Here we review the mechanism of action and efficacy of romiplostim for the treatment of thrombocytopenia in various diseases.

\section{TPO Signaling and Mechanism of Action}

As reviewed by Kuter and Begley, ${ }^{7}$ TPO is synthesized primarily in the liver as a single 353-amino acid precursor protein. Cleavage of the N-terminal 21-amino acid signal peptide reveals a mature molecule comprising two domains: a receptor binding domain and a highly glycosylated carboxy-terminus important for protein stability (Figure 1). ${ }^{7,8}$ TPO itself has been shown to be the most important growth factor for platelet production ${ }^{2,9}$ because it is involved in virtually all stages of platelet production from stem cell through mature megakaryocyte (and possibly platelet release). ${ }^{10,11}$ Plasma concentrations of TPO increase in response to a decline in platelet mass, especially if megakaryocyte numbers are reduced. Conversely, when platelet levels are high, TPO binds to its myeloproliferative leukemia virus (MPL) receptors on circulating platelets or megakaryocytes in the bone marrow (Figure 1). ${ }^{11}$ TPO has been

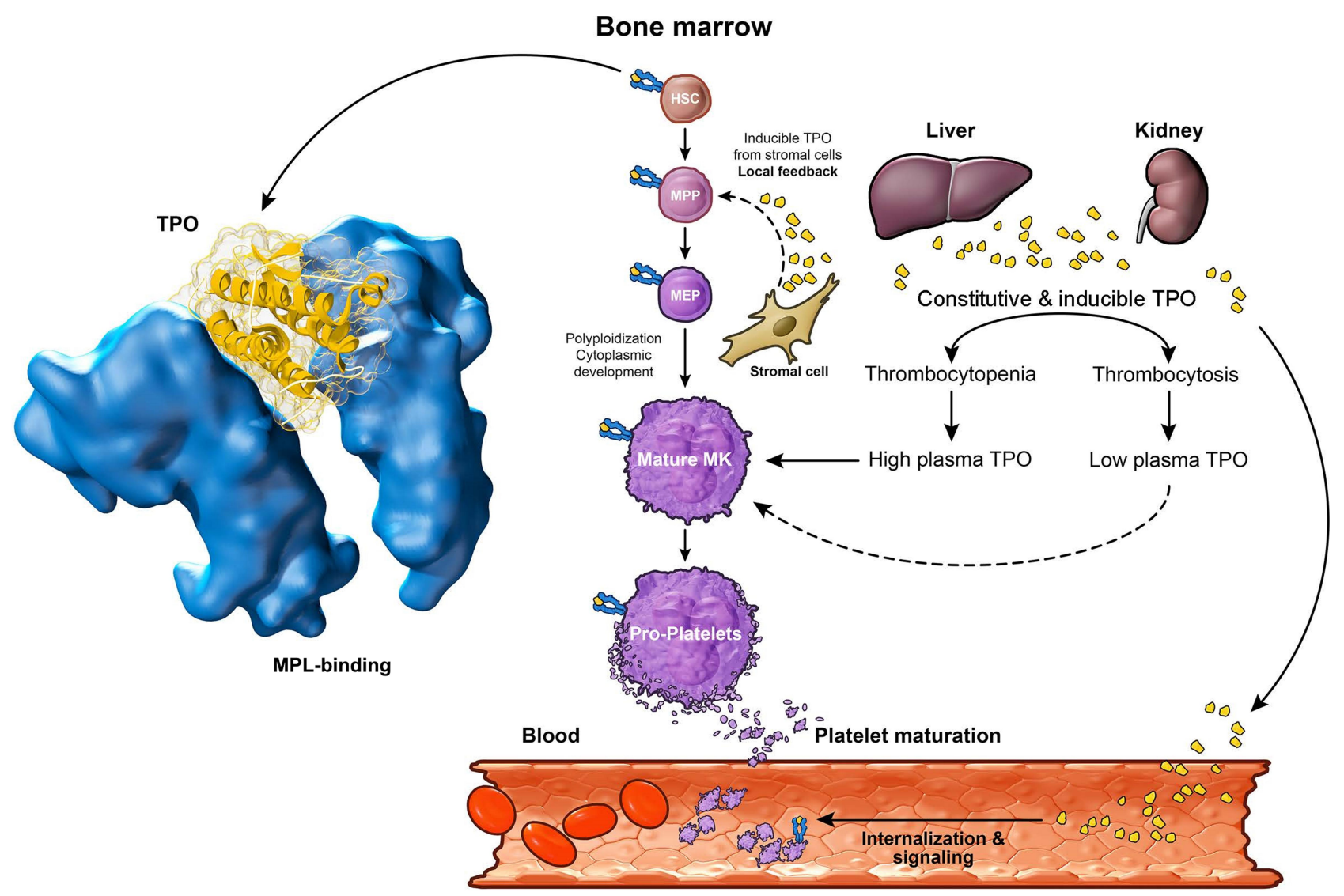

Figure I Structure of thrombopoietin ${ }^{7,8}$ and TPO-MPL signaling." Thrombopoietin is synthesized in the liver and kidney as a single 353 -amino acid precursor protein. Plasma concentrations of TPO increase in response to reduced platelet mass. Conversely, TPO binds to MPL receptors on circulating platelets in the blood when platelet levels are high. Upon exogenous TPO stimulation, HSCs differentiate to megakaryocytes. Local TPO production by stromal cells in the bone marrow also stimulates megakaryocyte maturation.

Abbreviations: HSC, hematopoietic stem cell; MEP, megakaryocyte-erythroid progenitor; MK, megakaryocytes; MPL, myeloproliferative leukemia virus; MPP, multipotent progenitors; TPO, thrombopoietin. 
shown to increase the size, ploidy, and number of megakaryocytes ${ }^{12,13}$ and stimulate expression of plateletspecific markers. ${ }^{12,14}$ When combined with other growth factors, TPO has a synergistic effect on the growth of myeloid and erythroid precursors ${ }^{15-17}$ and stimulates trilineage responses when used alone in severe aplastic anemia. ${ }^{18,19}$ In hematopoietic stem cells, stimulation of the TPO receptor (TPO-R) results in signaling that influences quiescence, selfrenewal, proliferation, and differentiation to megakaryocyte progenitors. ${ }^{11}$ TPO also affects genome stability (through ERK- and NF- $\kappa \mathrm{B}-$-mediated activation of Iex-1 to promote DNA-protein kinase-dependent nonhomologous end-joining repair $^{20}$ ), mitochondrial metabolism, and potentially iron metabolism in hematopoietic stem cells. In addition, TPO alters hematopoietic stem cell lineage differentiation via metabolic regulation. In turn, these functions may affect the outcome of TPO-MPL signaling in hematopoietic stem cells, ${ }^{11}$ areas in which TPO-RAs have unique and distinct effects. ${ }^{11}$ Along with increasing platelet production, TPORAs also appear to transiently extend their circulating life span, potentially via signaling through the AKT pathway and reducing sensitivity to apoptotic stimuli. ${ }^{21}$

\section{Mechanisms of ITP}

Platelet life span is reduced in patients with ITP. $^{22}$ Although the pathophysiology of ITP is not completely understood, evidence suggests it is a disease of platelet destruction and insufficient platelet production (Figure 2). ${ }^{23-26}$ The contribution of these pathologic mechanisms in individual patients is uncertain, but it is thought that antibodies and $\mathrm{T}$ cells affect both platelets and megakaryocytes. For example, insufficient megakaryopoiesis ${ }^{23,25}$ and impaired proplatelet formation ${ }^{27,28}$ have both been described as potential mechanisms leading to thrombocytopenia. Common mechanisms involved with platelet clearance include antibody and T-cell-dependent immune mechanisms, platelet apoptosis, and glycan modifications.

In patients with ITP, it has been proposed that antiglycoprotein IIb/IIIa (GPIIb/IIIa) autoantibody-coated platelets are targeted for destruction by macrophages through one of the following: activation of fragment crystallizable (Fc) $\gamma$, a process that is controlled by spleen tyrosine kinase and results in phagocytosis by macrophages or complement pathway receptors. ${ }^{29-32}$ Platelet antigens are thought to be presented by major histocompatibility complex class II antigens on the surface of the macrophages, thus stimulating autoreactive $\mathrm{T}$ cells. ${ }^{26}$ It is thought that the T-cell response is skewed toward activation of type 1
T-helper (Th1) and type 17 T-helper (Th17) cells, reduced regulatory T-cell (Treg) activity, and increased cytotoxic T-cell activity, with the latter possibly destroying platelets or inhibiting production by megakaryocytes. ${ }^{33-39}$ Additionally, platelet glycoprotein autoantibodies may inhibit megakaryocyte maturation. ${ }^{23,25,31}$

Approximately $70 \%$ of patients with chronic ITP have detectable serum autoantibodies that generally target GPIIb/ IIIa and/or GPIbIX; ${ }^{40-42}$ however, some patients with ITP have no detectable autoantibodies, yet their disease presentation is similar to those with antibodies. The presence of autoantibodies is not always associated with active disease. ${ }^{40,42}$ In these patients, cell-mediated immune mechanisms, such as CD8+ cells in bone marrow, might suppress megakaryocyte apoptosis, leading to impaired platelet production and thrombocytopenia. $^{36,43,44}$ Platelets can present antigens to CD8+ cells, indicating that they may also participate in the initiation of acquired immune responses in addition to supporting and promoting acquired immune responses. ${ }^{45}$ This characteristic of platelets is thought to arise from megakaryocytes. ${ }^{46}$ Evidence also suggests a role for increased classical pathway complement activation in ITP. ${ }^{47}$

Platelet survival is controlled by an intrinsic apoptotic program. The antiapoptotic protein Bcl-xL constrains the proapoptotic proteins Bak and Bax to maintain platelet survival; as Bcl-xL degrades, older platelets are primed for cell death. ${ }^{4,49}$ Genetic inactivation or pharmacologic inhibition of Bcl-xL leads to Bax-/Bak-induced mitochondrial damage and promotes the apoptotic cascade, reducing platelet half-life, and causing thrombocytopenia. ${ }^{48,49}$ Imbalanced expression of Bcl-xL and Bax has been associated with platelet apoptosis in ITP. ${ }^{50}$

Another method of platelet clearance appears to involve glycan modifications on platelet surface proteins, which may be triggered by the loss of terminal sialic acid residues on platelet surface glycoproteins as they age. B cells secreting anti-GPIb or anti-GPIIb/IIIa antibodies have been detected in plasma and are a hallmark of patients with ITP. ${ }^{51}$ These antibodies to GPIb $\alpha$, among other mechanisms, can also lead to neuraminidasemediated desialylation. Loss of the terminal sialic acid residues triggers recognition and uptake by the AshwellMorell receptor. ${ }^{49,52}$ Uptake of the desialylated platelets stimulates JAK-STAT signaling and upregulation of TPO mRNA expression by the same pathway as interleukin (IL)-6 in hepatocytes, leading to increased serum TPO levels and subsequent increase in megakaryopoiesis and platelet biogenesis. ${ }^{52-56}$ 


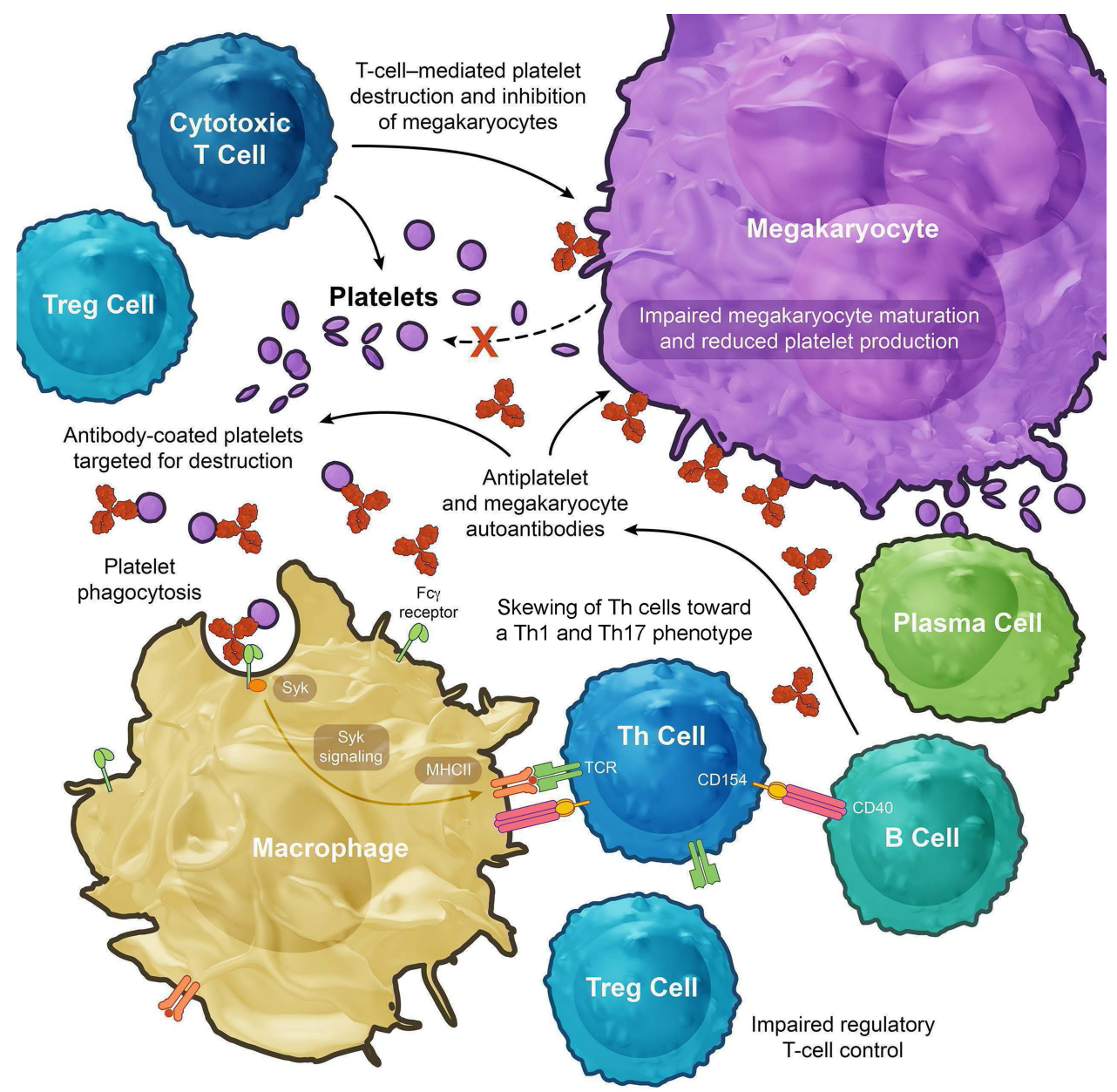

Figure 2 Pathophysiology of immune thrombocytopenia. ${ }^{26}$ Production of antiplatelet autoantibodies appears to be a key event in the pathophysiology of ITP. These autoantibodies target platelets for destruction by macrophages in the spleen or liver through activation of Fcy receptors, a process controlled by spleen Syk. Autoantibodies may also destroy platelets through other mechanisms and inhibit platelet production by megakaryocytes. Antigens from phagocytosed platelets are thought to be presented by the MHCll to TCRs, stimulating autoreactive T cells. Pathogenic T-cell changes seen in ITP include skewing of T-helper cells toward a type I T-helper (ThI) and type I7 T-helper (ThI7) phenotype, reduction of regulatory T-cell activity, and an increase in cytotoxic T cells. From N Engl J Med, Cooper N, Ghanima W. Immune Thrombocytopenia. 38I(10):945-955. Copyright @(2019) Massachusetts Medical Society. Reprinted with permission from Massachusetts Medical Society. ${ }^{26}$

Abbreviations: CD, cluster of differentiation; Fc $\gamma$, fragment crystallizable; ITP, immune thrombocytopenia; MHClI, major histocompatibility complex class II; Syk, tyrosine kinase; TCR, T-cell receptor; ThI, type I T-helper; Th 17, type 17 T-helper; Treg, regulatory T cell.

\section{Overview of the Structure, Mechanism of Action, and Pharmacokinetics/} Pharmacodynamics of Romiplostim

Romiplostim is a peptibody comprising four TPO-R binding domains (identified by screening mutagenesis peptide libraries $^{57}$ ) with high affinity for the TPO-R (MPL) and one carrier Fc domain ${ }^{4,5,58,59}$ and has no sequence homology with endogenous TPO (Figure 3). ${ }^{4,58,60}$ Romiplostim binds to and activates the TPO-R on megakaryocyte precursors in bone marrow. ${ }^{58}$ It binds in the same manner as endogenous TPO and can displace TPO from its receptor. ${ }^{3,59}$ Romiplostim activates many of the same pathways as TPO, leading to sustained improvement of platelet counts with continued treatment in patients with ITP. ${ }^{61-64}$ Preclinical and clinical data suggest that romiplostim also has immunomodulatory effects. $^{65,66}$

One study in mice suggested that romiplostim not only significantly raised platelet counts but also lowered antiplatelet antibody levels. ${ }^{66}$ In humans, romiplostim was shown to improve in vitro Treg function in patients with chronic ITP. Although the mechanism behind Treg normalization is unclear, it is hypothesized that this is caused by the increased plasma levels of transforming growth factor-beta resulting from increased platelet turnover secondary to increased platelet production. ${ }^{65}$

Much less is known about the effects mediated by the Fc region of the molecule and any immunomodulatory effects that may occur by specifically binding with Fc 


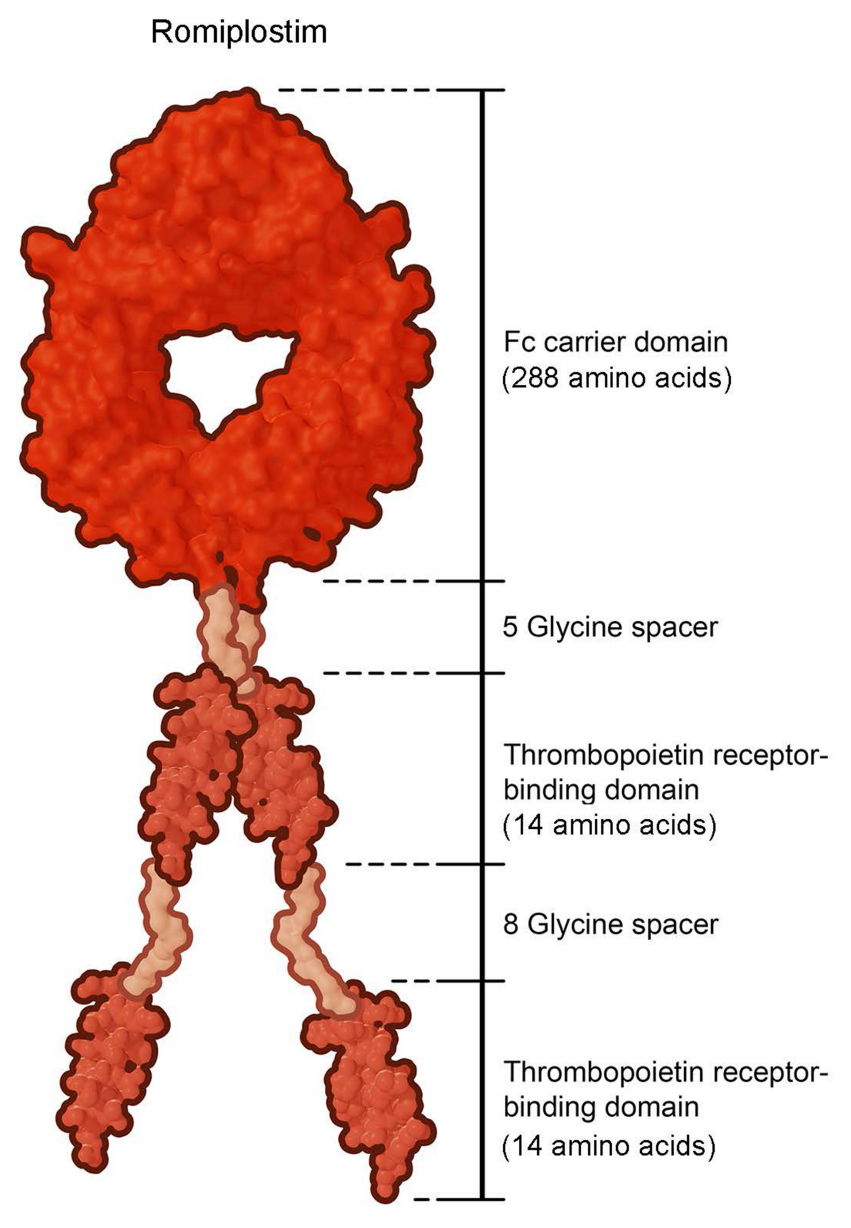

Figure 3 Chemical structure of romiplostim. ${ }^{60}$ Romiplostim (molecular weight $\approx 60 \mathrm{kDa}$ ) is a peptibody composed of four identical thrombopoietin peptides of 14 amino acids each that are chemically coupled by glycine spacer domains to the carboxy-terminus of the Fc carrier domain. These 14 amino acid peptides have no sequence homology with native thrombopoietin.

Abbreviation: Fc, fragment crystallizable.

receptors and thereby affecting various immune responses. ${ }^{67}$ Interaction with the Fc $\gamma$ receptors may allow romiplostim to modify maintenance of humoral tolerance, cell maturation, antigen presentation, and Treg expansion. Finally, romiplostim may be capable of activating Tregs through two epitopes of the Fc region termed Tregitopes. Further exploration of these mechanisms in the function of peptibodies is warranted. ${ }^{67}$

Binding of romiplostim activates a wide range of signaling pathways that promote cell viability, cell growth, megakaryocyte endomitosis, megakaryocyte maturation, and importantly, platelet production (Figure 4). ${ }^{3,59,68}$ Different TPO-RAs activate the TPO-R in different ways. For example, romiplostim activates the extracellular domain of the TPO-R, whereas eltrombopag and avatrombopag activate the transmembrane portion of the TPO-R (Figure 4$),{ }^{3}$ which could lead to different levels of activity of the TPO-R and hence different responses within the stem cell and megakaryocyte compartments. Data from Broudy and $\operatorname{Lin}^{59}$ and Currao et $\mathrm{al}^{68}$ indicate that binding of romiplostim results in tyrosine phosphorylation and subsequent activation of Mp1, JAK2-STAT5, ERK1/2, and AKT downstream signaling pathways leading to gene transcription and increased megakaryocyte proliferation and differentiation. Similar to endogenous TPO, romiplostim stimulates growth of megakaryocyte colony-forming cells and increases megakaryocyte number, size, and ploidy. ${ }^{59,60}$ Studies of platelets suggest that signaling in platelets was similar for romiplostim and eltrombopag; the role of intracellular iron chelation in the effect of eltrombopag is unique, but its clinical impact is not known. ${ }^{3,69}$ Altogether, these characteristics of romiplostim clarify the reasons why it is a good treatment option for ITP and may be useful in other hematologic conditions that result in thrombocytopenia.

The pharmacokinetics and pharmacodynamics of romiplostim have been evaluated by Wang et al. ${ }^{58,70}$ In brief, among healthy volunteers, platelet counts increased 1 to 3 days after intravenous administration and 4 to 9 days after subcutaneous administration, peaking on days 12 to $16^{58}$ Pharmacokinetics of romiplostim dosing is nonlinear and dependent on the dose administered and baseline platelet counts. $^{58,70}$ After subcutaneous administration at doses ranging from 3 to $15 \mu \mathrm{g} / \mathrm{kg}$ (an early upper limit of ITP dosing), peak serum concentrations of romiplostim occurred at approximately 7 to 50 hours posttreatment (median, 14 hours), and the half-life was approximately 1 to 34 days (median, 3.5 days). ${ }^{5}$ Models suggest that romiplostim activity is driven by saturation of receptor occupancy on platelets and megakaryocytes rather than the romiplostim serum concentration. ${ }^{71}$

\section{Clinical Evidence and Rationale for Use of Romiplostim in Chronic ITP}

A large body of evidence supports the use of romiplostim to safely and effectively increase platelet counts in adults and children with ITP. Table 1 lists some key studies on the efficacy and safety of romiplostim in adult and pediatric patients with ITP. In adults, romiplostim increased platelet counts and reduced the rate of bleeding events in multiple Phase 1, 2, and 3 clinical trials for up to 52 weeks $^{61,62,72,73}$ and long-term extension studies or pooled analyses for up to 5.4 years. ${ }^{63,74-76}$ In pediatric populations, platelet responses were observed up to 24 weeks in 


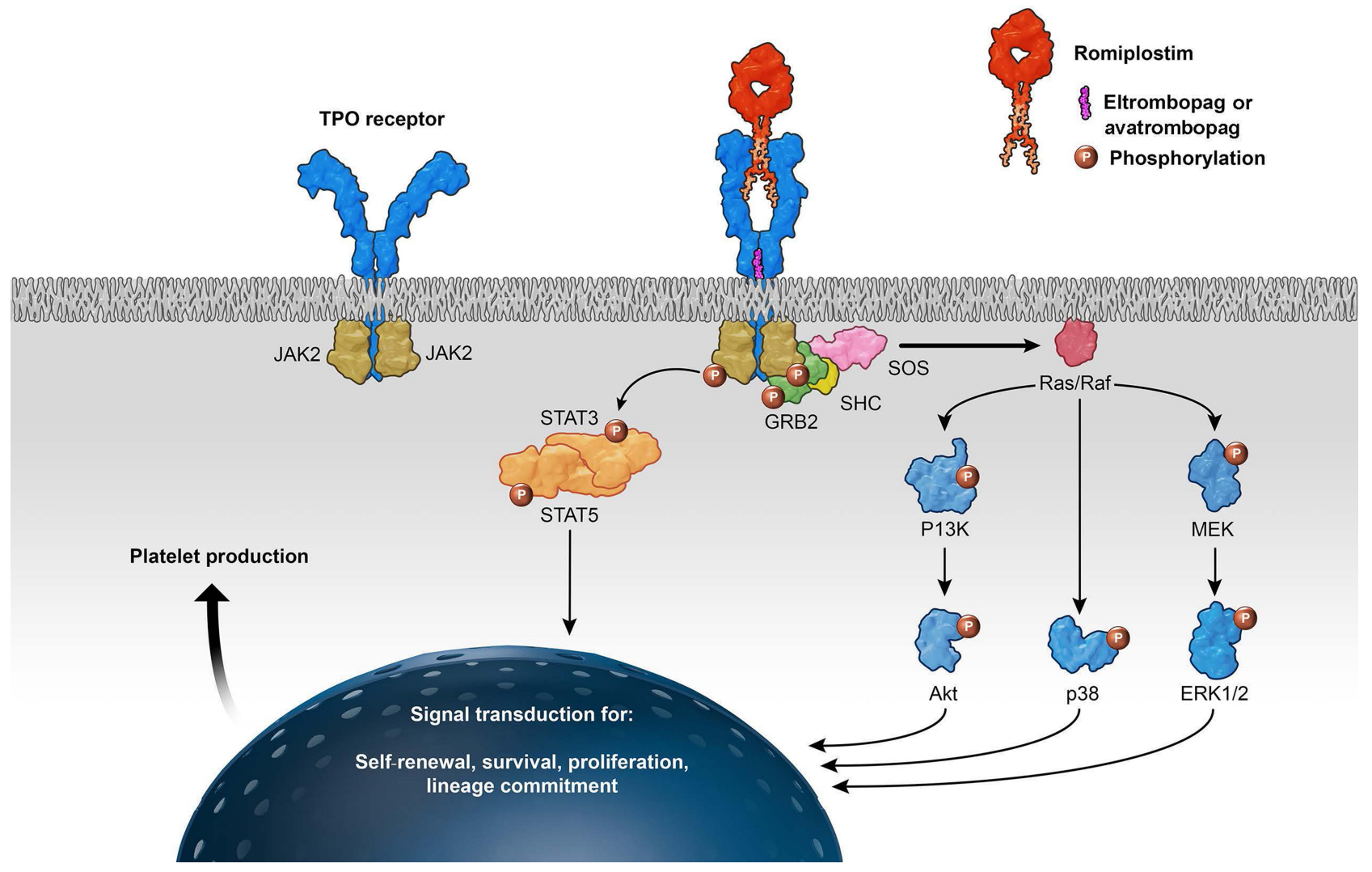

Figure 4 Cellular mechanism of action of thrombopoietin receptor agonists. ${ }^{3}$ Binding of the ligand (TPO/TPO-RA) to the c-MPL receptor on the megakaryocyte causes conformational change in the receptor, resulting in downstream activation of the various signaling pathways, including JAK2/STAT5, PI3K/Akt, MEK/ERK, and p38, ultimately resulting in increased platelet production. Various pathways can be activated by the different substances. Romiplostim activates the extracellular domain of the TPO-R and eltrombopag and avatrombopag activate the transmembrane portion of the TPO-R.

Abbreviations: Akt, protein kinase B; ERK, extracellular-signal-regulated kinase; GRB2, growth factor receptor-binding protein 2; JAK, Janus kinase; MEK, mitogenactivated protein kinase/ERK kinase; MPL, myeloproliferative leukemia virus; P, phosphorylation; PI3K, phosphatidylinositol 3-kinase; Raf, rapidly accelerated fibrosarcoma kinase; Ras, rat sarcoma GTPase; SHC, Src homology collagen protein; SOS, Son of Sevenless; STAT, signal transducer and activator of transcription; TPO, thrombopoietin; TPO-RA, thrombopoietin receptor agonist.

clinical trials ${ }^{77,78}$ and for up to 7 years in long-term extension studies. ${ }^{79,80}$ In the extension study in pediatric patients with chronic ITP, romiplostim was associated with a treatment-free response (defined as a platelet count $\geq 50$ $\times 10^{9} / \mathrm{L}$ for $\geq 6$ months with no ITP medications) in 15 patients $(23 \%)$. Only one patient later experienced relapse at week 67 after about 30 weeks withholding romiplostim. The patient received romiplostim in weeks 68 to 96 and stopped all ITP treatments in weeks 97 to 99 per protocol. The patient had consecutive platelet counts $\geq 340 \times 10^{9} /$ L. ${ }^{79}$ Data from observational, real-world studies, which often describe effects on concomitant medications, such as corticosteroid dose reduction or discontinuation, have also shown that romiplostim often improved platelet counts and reduced bleeding events and hospitalizations in patients. ${ }^{81,82}$ The efficacy and safety results were similar to those observed in clinical trials. ${ }^{81}$
Patients have also maintained sustained platelet counts after discontinuing romiplostim; $;^{73,83-86}$ whether this is related to romiplostim or reflects spontaneous improvement of ITP is not known. Ghadaki et al found nine of 31 patients (29\%) with ITP had sustained remissions, six of whom (19\%) received romiplostim; in most of these cases, once platelet response was achieved, the medication was slowly tapered until it was successfully discontinued. ${ }^{85}$ In a case series reported by MingotCastellano et al, four patients achieved sustained response (two of whom had chronic ITP), with the time to romiplostim taper and discontinuation ranging from 1 to 52 weeks and 14 weeks to 18 months, respectively. ${ }^{86}$ Carpenedo et al found that 13 of 27 patients (48\%, six of whom had chronic ITP) were able to discontinue romiplostim after a mean of 43.3 weeks of therapy; continued treatment-free response was maintained for a mean of 28.8 
Table I Key Phase 3 and Long-Term Studies on the Efficacy and Safety of Romiplostim in Patients with Chronic and Early Stage ITP

\begin{tabular}{|c|c|c|c|c|}
\hline Study Design & $\begin{array}{r}\text { Study Details } \\
\text { n, Duration }\end{array}$ & $\begin{array}{l}\text { Weekly Initial } \\
\text { Romiplostim Dose }\end{array}$ & $\begin{array}{l}\text { Key Efficacy Results } \\
\text { Romiplostim versus } \\
\text { Comparator }\end{array}$ & $\begin{array}{l}\text { Key Safety Results } \\
\text { Romiplostim versus } \\
\text { Comparator }\end{array}$ \\
\hline \multicolumn{5}{|l|}{ Adults } \\
\hline $\begin{array}{l}\text { Phase } 3 \\
\text { Two parallel, } \\
\text { prospective, multicenter, } \\
\text { placebo-controlled, } \\
\text { double-blind }^{62}\end{array}$ & $\begin{array}{l}\text { I25 Splen and Nonsplen } \\
\text { (83 romiplostim; } 42 \\
\text { placebo) } \\
24 \text { weeks }\end{array}$ & $\mathrm{I} \mu g / \mathrm{kg}$ & 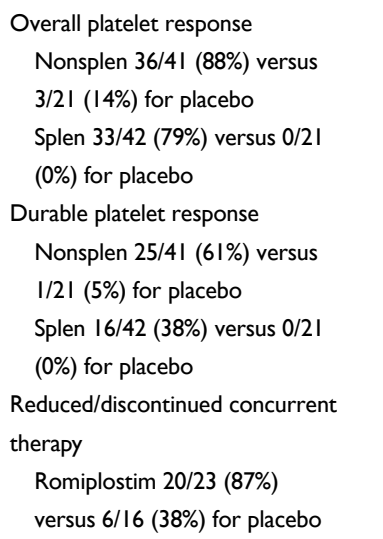 & $\begin{array}{l}\text { Significant bleeding events } \\
\text { Romiplostim } 6 / 84 \text { (7\%) versus } \\
5 / 4 \text { I (I2\%) for placebo } \\
\text { No antibodies against romiplostim or } \\
\text { TPO were detected }\end{array}$ \\
\hline $\begin{array}{l}\text { Phase } 3 \\
\text { Multicenter, randomized, } \\
\text { controlled, open-label }^{63}\end{array}$ & $\begin{array}{l}234 \text { Nonsplen } \\
\text { (157 romiplostim; } 77 \\
\text { SOC) } \\
52 \text { weeks }\end{array}$ & $3 \mu g / \mathrm{kg}$ & $\begin{array}{l}\text { Response rate } \\
2.3 \text {-fold higher for } \\
\text { romiplostim versus SOC } \\
\text { Treatment failure } \\
\text { 18/157 (1 } 1 \% \text { ) versus } 23 / 77 \\
\text { (30\%) for SOC } \\
\text { Splenectomy } \\
\text { 14/157 (9\%) versus } 28 / 77 \\
\text { (36\%) for SOC }\end{array}$ & $\begin{array}{l}\text { Bleeding events } \\
3.6 \text { versus } 5.0 \text { per } 100 \text { weeks for } \\
\text { SOC } \\
\text { Serious AEs } \\
35 / 154 \text { ( } 23 \% \text { ) versus } 28 / 75(37 \%) \\
\text { for SOC }\end{array}$ \\
\hline $\begin{array}{l}\text { Phase } 3 \mathrm{~b} \\
\text { Long-term, open-label, } \\
\text { single-arm study }{ }^{202}\end{array}$ & $\begin{array}{l}407 \text { Splen and Nonsplen } \\
44 \text { weeks (median) }\end{array}$ & $\mathrm{I} \mu g / \mathrm{kg}$ & $\begin{array}{l}\text { Platelet response } \\
370 / 407(91 \%) \text { achieved } \\
\text { a platelet count } \geq 50 \times 10^{9} / \mathrm{L} \text { that was } \\
\text { at least double their baseline count }\end{array}$ & $\begin{array}{l}\text { Treatment-related serious AEs } \\
29 / 407(7 \%) \text {; rate of } 0.2 \text { per } 100 \\
\text { weeks } \\
\text { Serious hemorrhagic events } \\
\quad 32 / 407(8 \%) \text {; rate of } 0.4 \text { per } 100 \\
\text { patient-weeks }\end{array}$ \\
\hline $\begin{array}{l}\text { Long-term, open-label } \\
\text { extension }{ }^{75}\end{array}$ & $\begin{array}{l}142 \\
\text { Up to } 156 \text { weeks (mean } \\
69 \text { weeks) }\end{array}$ & $\begin{array}{l}\text { I } \mu g / \mathrm{kg} \text { or at dose } \\
\text { received in parent study }\end{array}$ & $\begin{array}{l}\text { Platelet response } \\
124 / 142(87 \%) \text { at any time and } \\
\text { during } 67 \% \text { of the weeks on } \\
\text { study } \\
\text { Discontinue/dose reduction } \\
\text { concurrent treatment } \\
16 / 32(50 \%) \text { and } 11 / 32(34 \%) \\
\text { reduced their dose by } \geq 25 \%\end{array}$ & $\begin{array}{l}\text { Treatment-related serious AEs } \\
\text { 13/142 (9\%) } \\
\text { Severe bleeding events } \\
\text { 12/142 (9\%) } \\
\text { Thrombotic events } \\
\text { 7/142 (5\%) }\end{array}$ \\
\hline $\begin{array}{l}\text { Long-term, open-label } \\
\text { extension }^{74}\end{array}$ & $\begin{array}{l}292 \text { Splen and Nonsplen } \\
\text { Up to } 277 \text { weeks (mean } \\
\text { I } 10 \text { weeks) }\end{array}$ & $\begin{array}{l}\text { I } \mu g / \mathrm{kg} \text { or at dose } \\
\text { received in parent study }\end{array}$ & $\begin{array}{l}\text { Platelet response } \\
95 \% \text { at any time } \\
97 \% \text { Nonsplen and } 90 \% \text { Splen } \\
\text { Maintained by all patients on } \\
\text { a median of } 92 \% \text { of study visits }\end{array}$ & $\begin{array}{l}\text { Treatment-related serious AEs } \\
24 / 291 \text { ( } 8 \% \text { ); rate of } 0.1 \text { per } 100 \\
\text { patient-weeks and no increase in } \\
\text { frequency over time } \\
\text { Bleeding events } \\
\text { Rate of } 2.8 \text { per } 100 \text { patient-weeks } \\
\text { (any bleeding event); most events } \\
\text { were mild/moderate in severity } \\
\text { Thrombotic events } \\
\text { 19/291 (7\%) }\end{array}$ \\
\hline
\end{tabular}

(Continued) 
Table I (Continued).

\begin{tabular}{|c|c|c|c|c|}
\hline Study Design & $\begin{array}{r}\text { Study Details } \\
\text { n, Duration }\end{array}$ & $\begin{array}{l}\text { Weekly Initial } \\
\text { Romiplostim Dose }\end{array}$ & $\begin{array}{l}\text { Key Efficacy Results } \\
\text { Romiplostim versus } \\
\text { Comparator }\end{array}$ & $\begin{array}{l}\text { Key Safety Results } \\
\text { Romiplostim versus } \\
\text { Comparator }\end{array}$ \\
\hline Pooled analysis $^{76}$ & $\begin{array}{l}\text { IIII: Splen (395) and } \\
\text { Nonsplen (7|6) } \\
\text { Splen: Up to } 281 \text { (mean } \\
\text { 87) weeks; Nonsplen: Up } \\
\text { to } 283 \text { (mean 82) weeks }\end{array}$ & $\begin{array}{l}\text { I } \mu \mathrm{g} / \mathrm{kg} \\
\text { Romiplostim exposure: } \\
702 \text { patient-years for } \\
\text { Splen and I } 30 \text { for } \\
\text { Nonsplen }\end{array}$ & $\begin{array}{l}\text { Platelet response } \\
\text { Splen: } 310 / 376 \text { (82\%); } 68 \% \text { with } \\
\text { sustained response } \\
\text { Nonsplen: } 592 / 648 \text { (91\%); } 80 \% \\
\text { with sustained response }\end{array}$ & $\begin{array}{l}\text { Treatment-related serious AEs (Splen } \\
\text { versus Nonsplen) } \\
9.3 \text { versus } 5.2 \text { per } 100 \text { patient- } \\
\text { years } \\
\text { Hemorrhagic events (Splen versus } \\
\text { Nonsplen) } \\
266 \text { versus } 141 \text { per } 100 \text { patient- } \\
\text { years } \\
\text { Thrombotic events (Splen versus } \\
\text { Nonsplen) } \\
6.3 \text { versus } 4.6 \text { per } 100 \text { patient- } \\
\text { years }\end{array}$ \\
\hline \multicolumn{5}{|l|}{ Pediatrics } \\
\hline $\begin{array}{l}\text { Phase } 3 \\
\text { Randomized, placebo- } \\
\text { controlled }^{78}\end{array}$ & $\begin{array}{l}62 \text { (42 romiplostim; } 20 \\
\text { placebo) } \\
24 \text { weeks }\end{array}$ & $\mathrm{I} \mu g / \mathrm{kg}$ & $\begin{array}{l}\text { Platelet response } \\
30 / 42(71 \%) \text { versus } 4 / 20(20 \%) \\
\text { for placebo } \\
\text { Durable platelet response } \\
22 / 42(52 \%) \text { versus } 2 / 20(10 \%) \\
\text { for placebo }\end{array}$ & $\begin{array}{l}\text { Serious AEs } \\
10 / 42(24 \%) \text { versus } 1 / 19(5 \%) \text { for } \\
\text { placebo } \\
\text { Serious bleeding events } \\
5 / 42(12 \%) \text { versus } 1 / 19(5 \%) \text { for } \\
\text { placebo } \\
\text { No thrombotic events reported }\end{array}$ \\
\hline Long-term extension ${ }^{79}$ & $\begin{array}{l}65 \\
\text { Up to } 7 \text { years (median } 2.6 \\
\text { years); } 182 \text { patient-years }\end{array}$ & $\mathrm{I} \mu \mathrm{g} / \mathrm{kg}$ & $\begin{array}{l}\text { Platelet response } \\
61 / 65 \text { ( } 94 \% \text { ) at any time } \\
47 / 65 \text { ( } 72 \% \text { ) for } \geq 75 \% \text { of the } \\
\text { time } \\
38 / 65 \text { ( } 58 \% \text { ) for } \geq 90 \% \text { of the } \\
\text { time } \\
\text { Treatment-free response }(\geq 24 \\
\text { weeks) } \\
\quad 15 / 65 \text { ( } 23 \%)\end{array}$ & $\begin{array}{l}\text { Serious AEs } \\
\quad 19 / 65 \text { ( } 29 \%) ; 41 \text { per } 100 \text { patient- } \\
\text { years } \\
\text { Serious bleeding events } \\
7 / 65 \text { (11\%) } \\
\text { No thrombotic events, fatalities, or } \\
\text { new safety concerns with } 182 \text { patient- } \\
\text { years of exposure to romiplostim }\end{array}$ \\
\hline \multicolumn{5}{|l|}{ Early ITP } \\
\hline $\begin{array}{l}\text { Phase } 2 \\
\text { Interventional, single- } \\
\mathrm{arm}^{73}\end{array}$ & $\begin{array}{l}75 \\
\text { ITP diagnosed } \leq 6 \text { months; } \\
\text { median (IQR) ITP } \\
\text { duration } 2.2(0.9,4.3) \\
\text { months } \\
\text { I2 months }\end{array}$ & $\mathrm{I} \mu g / \mathrm{kg}$ & $\begin{array}{l}\text { Platelet response } \\
70 / 75(93 \%) \text { during any I month } \\
\text { Median (IQR) number of months } \\
\text { with platelet response, II }(8,12) \\
\text { ITP remission } \\
24(32 \%)\end{array}$ & $\begin{array}{l}\text { Serious AEs } \\
\qquad 14(19 \%) ; 3(4 \%) \text { treatment } \\
\text { related } \\
\text { Bleeding episodes } \\
\quad 23(31 \%) \text {; none were serious }\end{array}$ \\
\hline Pooled analysis $^{102}$ & $\begin{array}{l}1037 \\
(3 \text { I I had ITP } \leq \text { I year; } 726 \\
\text { had ITP > I year) }\end{array}$ & Mostly I $\mu g / \mathrm{kg}$ & $\begin{array}{l}\text { Platelet response (ITP } \leq \text { I year } \\
\text { versus }>\text { I year) } \\
\text { Any: } 238 / 277(86 \%) \text { versus } \\
552 / 634(87 \%) \\
\text { Durable: } 147 / 277(53 \%) \\
\text { versus } 3 \text { | I/634 (49\%) }\end{array}$ & $\begin{array}{l}\text { Treatment-related serious AEs (ITP } \\
\leq 1 \text { year versus }>\text { I year) } \\
4 \text { versus } 7 \text { per } 100 \text { patient-years } \\
\text { Bleeding (ITP } \leq 1 \text { year versus }>\text { I year) } \\
\text { I } 30 \text { versus I } 82 \text { per } 100 \text { patient- } \\
\text { years } \\
\text { Thrombotic/thromboembolic events } \\
\text { (ITP } \leq 1 \text { year versus }>\text { I year) } \\
4 \text { versus } 6 \text { per } 100 \text { patient-years }\end{array}$ \\
\hline
\end{tabular}

Abbreviations: AE, adverse event; IQR, interquartile range; ITP, immune thrombocytopenia; Nonsplen, nonsplenectomized; SOC, standard of care; Splen, splenectomized; TPO, thrombopoietin. 
months. ${ }^{83}$ In a retrospective analysis, 11 of 46 patients $(24 \%)$ with relapsed or refractory ITP who received treatment with a TPO-RA were able to discontinue treatment after achieving a platelet response; seven of the 11 patients (64\%) received romiplostim for 2 to 36 months with a sustained response 16 to 54 months after discontinuation. ${ }^{84}$ In their retrospective analysis, Lozano et al found that out of 121 patients who received TPORAs, 41 patients (34\%) received romiplostim as their only TPO-RA (including 29 patients with chronic ITP). ${ }^{87}$ Despite the intention of long-term treatment at its initiation, 23 patients $(56 \%)$ tapered off romiplostim after different durations of treatment and were eligible for assessment of achieving treatment-free response (defined as maintaining a platelet count $\geq 50 \times 10^{9} / \mathrm{L}$ for at least 6 months without any ITP treatment); out of the 41 patients receiving romiplostim, 21 patients $(51 \%)$ achieved treatment-free response. Of the 29 patients with chronic ITP, 13 patients $(45 \%)$ achieved treatment-free response. These data reinforce that initiating romiplostim will not automatically require indefinite continuation of treatment, but rather, that a substantial fraction of patients will become and remain treatment-free with hemostatic counts.

Safety has been established for romiplostim treatment in patients with ITP for up to 5.4 years in adults and 7 years in children. ${ }^{76,79}$ The most frequently reported adverse events among adult romiplostim recipients were headache and fatigue. ${ }^{61-63,72-75}$ In a study in adults with ITP, two patients were diagnosed with hematopoietic malignancies (chronic lymphocytic leukemia in one patient; lymphoma in one patient who previously had peripheral leucocytosis); both patients had evidence of the disease prior to enrollment. ${ }^{74}$ Reports of neutralizing antibodies to romiplostim were infrequent, with no antibodies to TPO detected in adults. ${ }^{61-63,72-76}$ In a study in 65 children treated with romiplostim, neutralizing antibodies were detected after treatment in one patient $(1.5 \%)$ who had left the study to start other treatment. Tests were negative on retesting 3 and 6 months later. No patients developed anti-TPO neutralizing antibodies. ${ }^{79}$ In a study conducted by Wang et al in 245 patients with newly diagnosed ITP,${ }^{88}$ romiplostim did not result in neutralizing antibodies either to TPO or itself in adults with primary ITP. Alternatively, analysis of the pooled safety data from 14 trials $(\mathrm{N}=1059)$ that included pediatric $(\mathrm{n}=23)$ and adult $(n=1036)$ patients revealed that three patients (ages not reported) developed neutralizing antibodies to romiplostim, but these did not cross-react with endogenous TPO.
Surprisingly, there was no apparent clinical impact on romiplostim treatment in the one patient who continued treatment or in another patient who maintained platelet counts even though treatment had been discontinued. In the final patient, antibodies were detected at the end of the study. ${ }^{89}$ In another long-term study assessing the efficacy and safety of romiplostim in children with ITP $(\mathrm{N}=203), 7$ patients developed neutralizing antibodies to romiplostim; all discontinued treatment. In one patient who developed neutralizing antibodies to romiplostim, platelet counts decreased and rescue medicine was administered. Among the remaining patients, antibodies were detected $\geq 1$ year after treatment started, and no reduction in therapeutic effect was reported. One patient developed neutralizing antibodies to TPO, which occurred 100 weeks after treatment started and romiplostim was continued for about 4 months after detection of neutralizing antibodies. ${ }^{90}$

In other studies, concurrent ITP medication use in adults was discontinued or decreased in responders with romiplostim use. ${ }^{63,74,75}$ No randomized trial comparing romiplostim with placebo identified a significantly higher rate of thromboembolic events in patients treated with romiplostim; however, in a pooled analysis of 14 studies that included adults and children treated with romiplostim for up to 5.4 years, the rate of thrombotic events was 5.5 per 100 patient-years for both the romiplostim and placebo groups. ${ }^{89}$ Therefore, the $5 \%$ rate of thrombotic/ thromboembolic events in the long-term extension study of romiplostim being similar to the rate observed in an extension study of eltrombopag ${ }^{75,91}$ suggests that an incremental prothrombotic effect of treatment with thrombopoietic agents exists.

Another area of interest is bone marrow reticulin, which has been shown to be increased in pediatric and adult patients receiving TPO-RAs. ${ }^{92}$ In a pooled analysis of 13 studies, one of which included pediatric patients, 12 patients $(1.8 \%)$ in the romiplostim group experienced bone marrow reticulin (1.3 events per 100 patient-years); all had received high doses of romiplostim $(8-18 \mu \mathrm{g} / \mathrm{kg}$ / wk). ${ }^{93}$ In another pooled analysis that included pediatric, adult, and geriatric patients, 17 cases of bone marrow reticulin and one case of collagen were reported among those receiving romiplostim compared with one case of reticulin in placebo recipients. Among the 10 patients for whom reticulin grading was reported, the highest grade of 4 was reported in one patient, grade of 3 in four, grade of 2 in two, and grade of 1 in three. Among patients who received romiplostim, the rate of bone marrow events 
was 1.3 (18 cases) per 100 patient-years and 3.6 (6 cases) per 100 patient-years among patients on the highest dose $(>10 \mu \mathrm{g} / \mathrm{kg}){ }^{89}$ However, in a pooled analysis of adult patients from 13 studies treated for up to 5.4 years, the rate of increased bone marrow reticulin with romiplostim was low: 0.4/100 patient-years in splenectomized and 0.6/ 100 patient-years in nonsplenectomized patients. ${ }^{76}$ The overall consensus of the studies is that an increase in reticulin in some patients with ITP treated with romiplostim occurs. However, levels of reticulin infrequently achieve a significant level (grade 3, the highest in the consensus scoring system) and rarely, if ever, appear to have any clinical effects. Increased reticulin appears to be reversible upon discontinuation of romiplostim. ${ }^{94}$ It should also be noted that reticulin fibrosis has been incorrectly reported as myelofibrosis; the latter myeloproliferative disorder involves collagen fibrosis and not only reticulin, as seen with TPO agents. ${ }^{89}$

\section{Clinical Evidence and Rationale for Use of Romiplostim in Newly Diagnosed and Persistent ITP}

During the early phase of ITP, patients have an adaptive immune response, whereby autoimmunity is reversible (ie, increased production of proinflammatory cytokines, Th1 response) and autoreactive B-cell clones may be increased. It is during this period that encouraging treatment-free response may be possible. In contrast, late or progressive ITP is often associated with irreversible autoimmunity, as characterized by lasting cytokine imbalance, loss of immune tolerance, and the generation of difficult-totarget long-lived plasma cells. ${ }^{95}$ Other events occurring in later stages of ITP that may justify the need for early intensive medical treatment include B-cell clonal expansion, antibody affinity maturation, epitope spreading, the functional diversification of autoantibody effector functions, and the generation of long-lived memory populations that differ from primary B cells. ${ }^{96}$

Newly diagnosed patients who received more intensive initial treatment regimens appeared to show improved initial and late response rates, ${ }^{88,97-99}$ which is consistent with the theory that earlier treatment in any disease is potentially more curative than later treatment.

A Phase 3 study of dexamethasone with rituximab versus dexamethasone alone in newly diagnosed Italian adults with ITP showed that combination therapy improved 6-month sustained response (63\%) compared with monotherapy (36\%). ${ }^{99}$ Similarly, in a phase 3 study in newly diagnosed Danish patients with ITP, the sustained response rate at 6 months was $58 \%$ with dexamethasone plus rituximab compared with $37 \%$ with rituximab alone. Also, a significantly longer time to relapse was observed for patients who received dexamethasone plus rituximab. ${ }^{98}$ In a single-arm study of frontline dexamethasone plus eltrombopag in adults with ITP, $66.7 \%$ of patients experienced relapse-free survival at 12 months. ${ }^{97}$ In a prospective, randomized study in adult Chinese patients with primary ITP, recombinant human TPO with high-dose dexamethasone versus high-dose dexamethasone monotherapy resulted in a higher incidence of early overall response $(89.0 \%$ versus $66.7 \%$, respectively; $P<0.001)$, complete response $(75.0 \%$ versus $42.7 \% ; P<0.001)$, and sustained complete response at 6 months $(46.0 \%$ versus $32.3 \% ; P=0.043) .{ }^{88}$

Shorter ITP disease duration ( $\leq 1$ year) has been shown to be a positive predictor of remission following romiplostim therapy. ${ }^{100,101}$ Additionally, lower peak dose of romiplostim was an independent predictor of treatment-free response, suggesting that a better response intrinsically made a difference. ${ }^{100}$

One single-arm prospective study (referred to previously) investigated the use of romiplostim in patients with newly diagnosed and persistent ITP (adults with primary ITP duration $\leq 6$ months) (Table 1$){ }^{73}$ In a Phase 2 study in which patients received romiplostim at a median treatment duration of 51 weeks, 24 of 75 patients (32\%) maintained treatment-free platelet counts $>50 \times 10^{9} / \mathrm{L}$ without the need for any ITP therapy for at least 6 months, following discontinuation of romiplostim at 1 year. ${ }^{73}$ The platelet response rate in this 12 -month trial was $>90 \%$, median time to first response was approximately 2 weeks, and cumulative median duration of response was 11 months. $^{73}$ Pooled data from nine romiplostim studies $(\mathrm{N}=1037)$ has shown that romiplostim may be more effective in achieving treatment-free remission in patients with ITP for $<1$ year compared with those with longer disease duration. $^{102}$

A retrospective, long-term, multicenter follow-up study of 121 adults with ITP who had been treated with TPORAs assessed factors associated with treatment-free responses. Among patients in this retrospective study receiving only romiplostim $(\mathrm{n}=41)$ or eltrombopag $(n=41), 95.1 \%$ in each group were not exposed to switching. Despite the small number of patients, the probability of achieving a treatment-free response was 3.2 times 
higher among patients who only received romiplostim versus those who only received eltrombopag $(P=0.014)$. Overall, $51.3 \%$ of patients who received romiplostim versus $24.4 \%$ of those who received eltrombopag were able to stop treatment. Among the 12 patients with newly diagnosed or persistent ITP at the start of treatment who received romiplostim only, $8(67 \%)$ achieved treatmentfree response (defined as maintaining a platelet count $\geq 50$ $\times 10^{9} / \mathrm{L}$ for at least 6 months without any ITP treatment). ${ }^{87}$ Other single-arm studies have not confirmed this discrepancy.

It is possible that the (single) Fc domain could contribute to the rate at which romiplostim results in a treatment-free response. In addition to the potential immunomodulatory roles described earlier, the possibility that the Fc domain could drive immune tolerance, perhaps through induction of Treg cells, ${ }^{103}$ needs to be studied further.

\section{Clinical Evidence and Rationale for Use of Romiplostim Beyond ITP}

Recent clinical evidence suggests a possible beneficial role of romiplostim in several disorders other than ITP that involve thrombocytopenia (Table 2).

\section{Chemotherapy-Induced Thrombocytopenia}

Chemotherapy-induced thrombocytopenia (CIT) is a common adverse effect of chemotherapeutic regimens that damage the bone marrow, depleting stem and progenitor cells and decreasing production of blood components pending restoration of the marrow. Chemotherapy agents can affect the megakaryocyte and platelet production pathway in different ways, such as affecting pluripotent stem cells or megakaryocyte progenitors, inhibiting nuclear factor kappa $\mathrm{B}$, increasing the rate of platelet destruction by reducing Bcl-xL activity, or enhancing platelet clearance by immune mechanisms. ${ }^{104}$

It was estimated that nearly $10 \%$ of patients treated with chemotherapy experience clinically significant CIT during at least one cycle of their treatment. ${ }^{105}$ Current management for CIT includes platelet transfusions, which are reserved for patients with severe thrombocytopenia. ${ }^{104}$ Chemotherapy treatment delays and dose reductions are often used to manage CIT, which lead to reduced relative dose intensity and, consequently, reduced efficacy of the chemotherapy regimen. ${ }^{106,107}$ A recent study investigated the effects of the antifibrinolytic drug tranexamic acid in preventing therapy-induced thrombocytopenia in patients undergoing treatment for hematologic malignancies; however, early results indicate that prophylactic tranexamic acid had no effect on the incidence of bleeding. ${ }^{108}$ This suggests that a potential way to treat CIT is to increase platelet counts. Therefore, an unmet need exists for alternative treatment options for CIT to maintain chemotherapy dose intensity and treatment schedules.

The utility of romiplostim to prevent or treat CIT has been examined in preclinical studies, ${ }^{109}$ case reports, ${ }^{110,111}$ retrospective analyses, ${ }^{112-114}$ and clinical studies. ${ }^{115-117}$ Preclinical data from McElroy et al indicate that there is an inverse relationship between platelet counts and endogenous TPO concentration in mice subjected to chemotherapy/radiation therapy; romiplostim enhanced platelet recovery particularly when administered in high doses $(\geq 100 \mu \mathrm{g} / \mathrm{kg}$; an order of magnitude above the highest recommended dose in ITP of $10 \mu \mathrm{g} / \mathrm{kg})^{5,6,109}$ A phase 2 trial investigated romiplostim compared with observation in patients with solid tumors. ${ }^{117}$ Because of promising results from an interim analysis that included a crossover part and lack of evidence that untreated control patients would experience corrected thrombocytopenia with additional time, the study was converted to a single-arm, openlabel study after institutional review board approval; in 60 patients with solid tumors and thrombocytopenia, romiplostim was able to significantly increase platelet count, reverse CIT, and reduce the recurrence of CIT in approximately $85 \%$ of patients. Most patients who achieved platelet correction after receiving romiplostim were able to resume the same chemotherapy regimen that resulted in CIT. $^{117}$ In a study of 15 patients with hematologic (four patients) and nonhematologic (11 patients) malignancies undergoing chemotherapy, $13(87 \%)$ achieved a platelet response, with 11 patients $(73 \%)$ achieving platelet counts $>100 \times 10^{9} / \mathrm{L}$ allowing continuation of full-dose chemotherapy. ${ }^{115}$ There are several planned or ongoing studies in patients with CIT. ${ }^{118-120}$ The optimal dosing regimen for romiplostim in the management of CIT will likely depend on the chemotherapy regimen being administered, the degree of platelet suppression expected, the time to reach the nadir, and the time to recovery of platelets. A multicenter study of romiplostim for CIT treatment in patients with solid tumors and lymphoid malignancies found a median optimized dose of $3 \mu \mathrm{g} / \mathrm{kg}$ for the entire cohort; the same median optimized dose was found for subcohorts of patients with solid tumors or hematologic 
Table 2 Key Clinical Studies of Romiplostim in Various Clinical Disorders Other Than ITP

\begin{tabular}{|c|c|c|c|c|c|}
\hline Study Type & $\begin{array}{l}\text { Patients } \\
\text { n, Attributes }\end{array}$ & $\begin{array}{l}\text { Intervention } \\
\text { Dose, Duration }\end{array}$ & Efficacy & $\begin{array}{l}\text { Treatment-Related } \\
\text { AEs }\end{array}$ & Key Interpretations \\
\hline \multicolumn{6}{|c|}{ Chemotherapy-induced thrombocytopenia } \\
\hline Prospective ${ }^{1 / 5}$ & $\begin{array}{l}\text { I5, adults, } \\
\text { nonhematologic } \\
\text { cancer }(n=11) \text { and } \\
\text { lymphoma }(n=4) \text { with } \\
\text { postchemotherapy } \\
\text { thrombocytopenia }\end{array}$ & $\begin{array}{l}\text { Romiplostim: median } \\
\text { (range) starting dose, I } \\
(\mathrm{I}-3) \mu g / \mathrm{kg}, \text { median } \\
\text { (range) maintenance } \\
\text { dose, } 3(\mathrm{I}-4) \mu g / \mathrm{kg} \text {; } \\
\text { median (range) } \\
\text { duration, } 50(7-322) \\
\text { days }\end{array}$ & $\begin{array}{l}87 \% \text { achieved } \\
\text { response } \\
73 \% \text { had platelet } \\
\text { counts }>100 \times 10^{9} / \mathrm{L}\end{array}$ & $\begin{array}{l}\text { No treatment-related } \\
\text { toxicity and no } \\
\text { hemorrhagic events } \\
\text { reported }\end{array}$ & $\begin{array}{l}\text { Romiplostim achieved } \\
\text { an increase in platelet } \\
\text { counts and enabled the } \\
\text { continued use of full- } \\
\text { dose chemotherapy in } \\
\text { the majority of patients }\end{array}$ \\
\hline $\begin{array}{l}\text { Randomized } \\
\text { comparison } \\
\text { versus } \\
\text { untreated } \\
\text { observation; } \\
\text { converted to } \\
\text { open-label } \\
\text { romiplostim } \\
\text { arm }^{117}\end{array}$ & $\begin{array}{l}60 \text { (comparative arm: } \\
\text { romiplostim, } n=15 ; \\
\text { observation, } n=8 \text { ), } \\
\text { adults with solid } \\
\text { tumors and } \\
\text { postchemotherapy } \\
\text { thrombocytopenia } \\
\text { despite reduction in } \\
\text { dose and delay of } \\
\text { chemotherapy }\end{array}$ & $\begin{array}{l}\text { Romiplostim: starting } \\
\text { dose } 2 \mu g / \mathrm{kg} \text { weekly, } \\
\text { increased by I } \mu g / \mathrm{kg} \\
\text { for up to } 3 \text { weeks, } \\
\text { mean (range) dose, } 2.6 \\
(\mathrm{I} .9-4.4) \mu g / \mathrm{kg} \text { weekly; } \\
\text { duration of } \\
\text { comparative arm, } 3 \\
\text { weeks; open-label } \\
\text { romiplostim continued } \\
\text { for up to } 34 \text { months }\end{array}$ & $\begin{array}{l}\text { In comparative arm, } \\
93 \% \text { of romiplostim } \\
\text { patients achieved } \\
\text { platelet counts } \geq 100 \\
\times 10^{9} / \mathrm{L} \text { within } 3 \\
\text { weeks versus } 12.5 \% \\
\text { of untreated patients } \\
\text { Across all treated } \\
\text { patients, } 85 \% \\
\text { achieved platelet } \\
\text { correction, } 64 \% \text { of } \\
\text { whom resumed } \\
\text { chemotherapy with } \\
\text { same dose/regimen }\end{array}$ & $\begin{array}{l}10 \% \text { of patients } \\
\text { developed a VTE } \\
\text { during first } 12 \text { months } \\
\text { of treatment } \\
\text { Romiplostim was not } \\
\text { discontinued in these } \\
\text { patients }\end{array}$ & $\begin{array}{l}\text { Romiplostim is more } \\
\text { effective than no } \\
\text { treatment in } \\
\text { correcting } \\
\text { thrombocytopenia } \\
\text { associated with } \\
\text { chemotherapy; } \\
\text { ongoing romiplostim } \\
\text { can enable resumption } \\
\text { of chemotherapy }\end{array}$ \\
\hline $\begin{array}{l}\text { Single-arm, } \\
\text { multi-center } \\
\text { study }^{|2|}\end{array}$ & $\begin{array}{l}\text { I73 (I53 with solid } \\
\text { tumors, } 20 \text { with } \\
\text { hematologic } \\
\text { malignancy) }\end{array}$ & $\begin{array}{l}\text { Open-label } \\
\text { romiplostim, median } \\
(\mathrm{IQR}) \text { starting dose, } 3 \\
(2-3) \mu g / \mathrm{kg} \text {, weekly or } \\
\text { intracycle for solid } \\
\text { tumor; } 3 \text { (2-4) } \mu \mathrm{g} / \mathrm{kg} \text {, } \\
\text { weekly or intracycle } \\
\text { for hematologic } \\
\text { malignancy }\end{array}$ & $\begin{array}{l}85 \% \text { of all solid tumor } \\
\text { patients achieved } \\
\text { platelet count } \geq 100 \times \\
10^{9} / \mathrm{L} \text { within a median } \\
\text { of } 9 \text { days }\end{array}$ & $\begin{array}{l}21 \% \text { of patients with } \\
\text { solid tumors had } \\
\text { chemotherapy } \\
\text { intensity reductions } \\
\text { and II\% of patients } \\
\text { required platelet } \\
\text { transfusions while on } \\
\text { romiplostim }\end{array}$ & $\begin{array}{l}\text { Romiplostim is } \\
\text { effective for the } \\
\text { management of CIT in } \\
\text { patients with solid } \\
\text { tumors, as } \\
\text { demonstrated by } \\
\text { improved platelet } \\
\text { counts and low rates } \\
\text { of chemotherapy dose } \\
\text { reductions and } \\
\text { treatment delays, } \\
\text { bleeding, and platelet } \\
\text { transfusions }\end{array}$ \\
\hline \multicolumn{6}{|c|}{ Aplastic anemia } \\
\hline $\begin{array}{l}\text { Open-label, } \\
\text { dose- } \\
\text { adjustment, } \\
\text { phase } 2 / 3 \\
\text { clinical trial }^{\mid 31}\end{array}$ & $\begin{array}{l}3 \mathrm{I} \text {, adults ineligible or } \\
\text { refractory to } \\
\text { immunosuppressive } \\
\text { therapy }\end{array}$ & $\begin{array}{l}\text { Romiplostim: } 10 \mu \mathrm{g} / \mathrm{kg} \\
\text { weekly for } 4 \text { weeks, } \\
\text { adjusted from } 5-20 \mu \mathrm{g} / \\
\mathrm{kg} \text {; interim analysis at } \\
\text { I year }\end{array}$ & $\begin{array}{l}84 \% \text { had hematologic } \\
\text { response at week } 27 \\
\text { and } 81 \% \text { at week } 53 \\
\text { Median days to } \\
\text { response, } 37.0 ; 75 \% \\
\text { achieved transfusion } \\
\text { independence (week } \\
53 \text { ) }\end{array}$ & $\begin{array}{l}\text { Headache, muscle } \\
\text { spasms, ALT increased, } \\
\text { fibrin D dimer } \\
\text { increased, malaise, pain } \\
\text { in extremity }\end{array}$ & $\begin{array}{l}\text { Romiplostim appears } \\
\text { effective and well } \\
\text { tolerated in adults with } \\
\text { treatment-refractory } \\
\text { aplastic anemia }\end{array}$ \\
\hline
\end{tabular}

(Continued) 
Table 2 (Continued).

\begin{tabular}{|c|c|c|c|c|c|}
\hline Study Type & $\begin{array}{l}\text { Patients } \\
\text { n, Attributes }\end{array}$ & $\begin{array}{l}\text { Intervention } \\
\text { Dose, Duration }\end{array}$ & Efficacy & $\begin{array}{l}\text { Treatment-Related } \\
\text { AEs }\end{array}$ & Key Interpretations \\
\hline $\begin{array}{l}\text { Open-label, } \\
\text { dose-finding } \\
\text { phase } 2 \text { clinical } \\
\text { trial, followed } \\
\text { by long-term } \\
\text { extension }{ }^{18}\end{array}$ & $\begin{array}{l}35 \text {, adults refractory to } \\
\text { immunosuppressive } \\
\text { therapy }\end{array}$ & $\begin{array}{l}\text { Romiplostim: dose } \\
\text { finding, I-10 } \mu g / \mathrm{kg} \\
\text { weekly; extension } \\
\text { study, I-20 } \mu g / \mathrm{kg} \\
\text { weekly; up to } 3 \text { years }\end{array}$ & $\begin{array}{l}55 \% \text { of evaluable } \\
\text { patients had a platelet } \\
\text { response at year I } \\
30 \% \text { maintained } \\
\text { platelet response at } \\
\text { years } 2 \text { and } 3\end{array}$ & $\begin{array}{l}\text { Myalgia, fatigue, } \\
\text { dizziness }\end{array}$ & $\begin{array}{l}\text { Romiplostim appears } \\
\text { to stimulate } \\
\text { proliferation of } \\
\text { residual stem cells and } \\
\text { progenitor cells in } \\
\text { patients with } \\
\text { refractory aplastic } \\
\text { anemia }\end{array}$ \\
\hline \multicolumn{6}{|l|}{ Perisurgical } \\
\hline $\begin{array}{l}\text { Single-center, } \\
\text { retrospective } \\
\text { study }^{149}\end{array}$ & $\begin{array}{l}\text { I8, adults with pre- } \\
\text { operative } \\
\text { thrombocytopenia }\end{array}$ & $\begin{array}{l}\text { Romiplostim: median } \\
\text { (range) dose, } 3 \text { (I-7.5) } \\
\mu g / k g \text { weekly; median } \\
\text { (range) duration, } 4.2 \\
(0.6-50) \text { weeks }\end{array}$ & $\begin{array}{l}\text { All patients had an } \\
\text { increase in platelet } \\
\text { counts (median, } 98 \times \\
10^{9} / \mathrm{L} \text { ) } \\
\text { No surgical delays or } \\
\text { cancellations due to } \\
\text { thrombocytopenia }\end{array}$ & $\begin{array}{l}4 \text { postoperative } \\
\text { bleeding events } \\
\text { I patient developed } \\
\text { Foley catheter- } \\
\text { associated clot after } \\
\text { prostate surgery }\end{array}$ & $\begin{array}{l}\text { Romiplostim effectively } \\
\text { increases platelet } \\
\text { counts in patients with } \\
\text { thrombocytopenia to } \\
\text { enable surgery, } \\
\text { including major cardiac } \\
\text { and orthopedic } \\
\text { surgery }\end{array}$ \\
\hline $\begin{array}{l}\text { Single-center, } \\
\text { retrospective } \\
\text { study }^{148}\end{array}$ & $\begin{array}{l}48 \text {, adults with } \\
\text { preoperative } \\
\text { thrombocytopenia }\end{array}$ & $\begin{array}{l}\text { Romiplostim: median } \\
\text { (range) starting dose, } 3 \\
(1-10) \mu g / k g \text { weekly; } \\
\text { median (range) } \\
\text { duration, } 13(6-35) \\
\text { days }\end{array}$ & $\begin{array}{l}\text { A platelet count } \geq 100 \\
\times 10^{9} / \mathrm{L} \text { achieved in } \\
92 \% \text { of patients after } \\
3 \text { doses of } \\
\text { romiplostim, } 79 \% \\
\text { after } 2 \text { doses, and } \\
38 \% \text { after a single } \\
\text { dose }\end{array}$ & $\begin{array}{l}\text { No apparent } \\
\text { treatment-related AEs }\end{array}$ & $\begin{array}{l}\text { Romiplostim rapidly } \\
\text { increases platelet } \\
\text { count in most } \\
\text { thrombocytopenic } \\
\text { patients } \\
\text { preoperatively, to } \\
\text { enable surgical } \\
\text { (including cardiac, } \\
\text { orthopedic, and } \\
\text { neurosurgical) } \\
\text { procedures to be } \\
\text { undertaken safely and } \\
\text { on schedule }\end{array}$ \\
\hline \multicolumn{6}{|l|}{ Posttransplant } \\
\hline $\begin{array}{l}\text { Multicenter } \\
\text { retrospective } \\
\text { study of } \\
\text { romiplostim } \\
\text { and } \\
\text { eltrombopag } \\
\text { 162 }\end{array}$ & $\begin{array}{l}86 \text { (romiplostim, } n=35 ; \\
\text { eltrombopag, } n=5 \mathrm{I} \text { ), } \\
\text { adults and children } \\
\text { with persistent } \\
\text { thrombocytopenia } \\
\text { after allogeneic } \\
\text { hematopoietic stem } \\
\text { cell transplant }\end{array}$ & $\begin{array}{l}\text { Romiplostim: starting } \\
\text { (range) dose: I (I-7) } \\
\mu g / k g \text { weekly, } \\
\text { maximum (range) } \\
\text { dose: } 5(\mathrm{I}-10) \mu g / \mathrm{kg} \\
\text { weekly } \\
\text { Eltrombopag: starting } \\
\text { (range) dose, } 50 \\
(25-150) \mathrm{mg} / \mathrm{d}, \\
\text { maximum (range) dose } \\
75 \text { (25-I50) mg/d } \\
\text { Median (range) } \\
\text { duration, } 62(7-700) \\
\text { days }\end{array}$ & $\begin{array}{l}\text { ORR for platelet } \\
\text { recovery }\left(\geq 50 \times 10^{9} /\right. \\
\text { L) in } 72 \% \text { of patients } \\
\text { Median response at } \\
66 \text { (range, } 2-247) \\
\text { days; response } \\
\text { sustained after } \\
\text { treatment } \\
\text { discontinuation in } \\
81 \% \text { of patients }\end{array}$ & $\begin{array}{l}\text { No patients } \\
\text { discontinued } \\
\text { treatment due to AEs } \\
\text { Grade } 3-4 \text { liver } \\
\text { abnormalities and } \\
\text { fatigue observed in } \\
\sim 2 \% \text { of patients }\end{array}$ & $\begin{array}{l}\text { Romiplostim and } \\
\text { eltrombopag appear } \\
\text { effective in patients } \\
\text { with isolated } \\
\text { thrombocytopenia and } \\
\text { those with secondary } \\
\text { failure of platelet } \\
\text { recovery } \\
\text { posthematopoietic } \\
\text { stem cell transplant }\end{array}$ \\
\hline
\end{tabular}

(Continued) 
Table 2 (Continued).

\begin{tabular}{|c|c|c|c|c|c|}
\hline Study Type & $\begin{array}{l}\text { Patients } \\
\text { n, Attributes }\end{array}$ & $\begin{array}{l}\text { Intervention } \\
\text { Dose, Duration }\end{array}$ & Efficacy & $\begin{array}{l}\text { Treatment-Related } \\
\text { AEs }\end{array}$ & Key Interpretations \\
\hline $\begin{array}{l}\text { Multicenter, } \\
\text { prospective } \\
\text { study }^{169}\end{array}$ & $\begin{array}{l}24 \text {, adults with }>7 \text { days } \\
\text { thrombocytopenia } \geq 45 \\
\text { days after allogeneic } \\
\text { hematopoietic stem } \\
\text { cell transplant }\end{array}$ & $\begin{array}{l}\text { Romiplostim: dose } \\
\text { escalation from I-I0 } \\
\mu g / \mathrm{kg} \text { weekly; } \\
\text { median (range) dose, } 5 \\
(I-I I) \mu g / k g \text { weekly; } \\
\text { duration, } 12 \text { weeks }\end{array}$ & $\begin{array}{l}\text { I8 patients achieved } \\
\text { platelet count } \geq 50 \times \\
10^{9} / \mathrm{L} \text { (without } \\
\text { platelet transfusion) } \\
\text { Median (range) time } \\
\text { to response } 45 \\
(2 \mathrm{I}-77 \text { ) days; } 16 \\
\text { patients had a durable } \\
\text { platelet response }\end{array}$ & $\begin{array}{l}\text { Bone marrow biopsies } \\
\text { at } I 2 \text { weeks and I year } \\
\text { after the start of } \\
\text { treatment did not } \\
\text { show any increase in } \\
\text { marrow fibrosis }\end{array}$ & $\begin{array}{l}\text { Romiplostim appears } \\
\text { to be effective in } \\
\text { improving platelet } \\
\text { count in patients with } \\
\text { transfusion-dependent } \\
\text { thrombocytopenia }\end{array}$ \\
\hline
\end{tabular}

Abbreviations: AE, adverse event; ALT, alanine aminotransferase; CIT, chemotherapy-induced thrombocytopenia; IQR, interquartile range; ITP, immune thrombocytopenia; ORR, overall response rate; VTE, venous thromboembolism.

malignancy. Furthermore, romiplostim was found to be effective for the management of CIT in patients with solid tumors receiving various chemotherapy regimens. $^{121}$ Additional results of ongoing studies will help select the optimal dose of romiplostim in patients with CIT to minimize the chemotherapy delay or dose reduction, which may vary in efficacy according to the chemotherapy protocol and whether the bone marrow is involved by the malignancy. A meta-analysis of 16 studies examined the use of TPO-RA to either treat or prevent CIT in patients receiving chemotherapy. There was a significant reduction in chemotherapy dose delay or dose decrease, as well as a decrease in platelet transfusions, with TPO-RAs, with no apparent increased risk of thrombosis. $^{122}$ The primary question remains whether these important "practical" findings will translate into improved survival.

\section{Aplastic Anemia}

Acquired aplastic anemia is a clinical syndrome characterized by deficiency of red blood cells, neutrophils, monocytes, and platelets in the blood, as well as fatty replacement of the marrow with almost complete absence of hematopoietic precursor cells. Aplastic anemia does not usually have an evident cause but may be idiopathic or associated with an inciting agent. In either case, it is likely caused by cytotoxic T-cell autoreactivity that suppresses or destroys CD34+ multipotential hematopoietic cells. ${ }^{123}$ Activated cytotoxic $\mathrm{T}$ cells secrete cytokines such as tumor necrosis factor- $\alpha$ and interferon- $\gamma$ (IFN- $\gamma$ ) and increase nitric oxide synthase and nitric oxide production by marrow cells, leading to immune-mediated cytotoxicity and elimination of hemopoietic progenitor cells. ${ }^{124}$ Studies have shown that patients with aplastic anemia have high levels of circulating TPO, with no correlation between TPO levels and platelet count, as well as a trend for higher TPO levels in patients with more severe aplastic anemia. $^{125-127}$

Patients with aplastic anemia may be treated with immunosuppressants or receive a bone marrow transplant as part of first-line treatment. ${ }^{128}$ Notably, the TPO-RA eltrombopag has been approved for the treatment of patients with severe aplastic anemia in the United States and the European Union. ${ }^{128,129}$ Although not approved for use in aplastic anemia in the United States and the European Union, romiplostim is believed to similarly stimulate the proliferation of residual stem and progenitor cells in patients with aplastic anemia (approval has been received for refractory aplastic anemia in Japan and Korea). ${ }^{18}$ Romiplostim has been shown to produce a trilineage response in patients with aplastic anemia, increasing platelets as well as erythroid and neutrophil responses. $^{18,130}$ For example, Lee et al conducted a multicenter phase 2 study with a randomized, parallel, dose-finding phase ( 8 weeks) followed by a long-term open-label extension in adult patients with aplastic anemia refractory to immunosuppressive therapy. ${ }^{18}$ Of 35 patients in the study, all 10 patients who received romiplostim 10 $\mu \mathrm{g} / \mathrm{kg}$ showed platelet responses, $30 \%$ of whom showed erythroid responses and $60 \%$ showed neutrophil responses during the first 8 weeks. At week 9, platelet response was achieved in 10 of 33 patients $(30 \%)$ and appeared to be dose dependent, with responses in seven of 10 who received romiplostim $10 \mu \mathrm{g} / \mathrm{kg}$ and three of nine who 
received romiplostim $6 \mu \mathrm{g} / \mathrm{kg}$. Platelet responses at weeks 105 and 157 were maintained in 10 patients who received 3 to $20 \mu \mathrm{g} / \mathrm{kg}$ once weekly, and erythroid and neutrophil responses were observed in nine and five patients, respectively. A trilineage response was observed in five patients at weeks 53, 105, and 157. During weeks 53 to 157, dose tapering was permitted in patients with a stable platelet response, and three patients were able to discontinue romiplostim at 56, 483, and 490 days, respectively. Bone marrow cell assays also showed that improvement in platelet counts were associated with an increase in progenitor cells. Colony assay indicated that romiplostim influenced stimulation of primitive hematopoietic stem cells (CD34+ and $\mathrm{CD}^{3-}$ ) and enhanced differentiation of primitive hematopoietic stem cells to late progenitor cells. ${ }^{18}$ Confirmation of these results was recently reported from a multicenter, phase 2/3, open-label study of 31 Japanese and Korean patients with aplastic anemia refractory to immunosuppressive therapy; results for romiplostim (initial dose $10 \mu \mathrm{g} / \mathrm{kg}$ for the first 4 weeks, which is then adjusted from 5 to $20 \mu \mathrm{g} / \mathrm{kg}$ thereafter) showed that $84 \%$ and $81 \%$ of patients achieved any hematologic response at weeks 27 and 53, respectively, and trilineage response was $39 \%$ at week 53 . Finally, $75 \%$ of patients achieved transfusion independence by week 53. ${ }^{131}$ Romiplostim is now being investigated in 2 registrational trials in Japan and Korea for frontline treatment of aplastic anemia in combination with cyclosporin A plus antihuman thymocyte immunoglobulin (NCT03957694) and cyclosporin A alone (NCT04095936). ${ }^{132,133}$

Three retrospective studies assessed romiplostim in patients with eltrombopag-refractory aplastic anemia. In a report of 8 patients with severe disease, only $1(12.5 \%)$ responded to romiplostim (maximum dose, $10 \mu \mathrm{g} / \mathrm{kg}$ ), achieving a trilineage response and remaining transfusionindependent after 21.2 months of treatment. ${ }^{134}$ However, in the other two studies, which used a higher dose of romiplostim, response rates were better. Among 21 patients with severe disease, $16(76 \%)$ achieved hematologic responses in $\geq 1$ lineage at 3 months of romiplostim treatment (dose, $10-20 \mu \mathrm{g} / \mathrm{kg}$ ), and 10 patients (48\%) had a platelet response. Four patients (21\%) achieved trilineage response at week 12 . Among 10 patients who had been transfusion-dependent, two discontinued platelet transfusions, and three no longer required packed red cells. ${ }^{135}$ Similarly, in another study of 10 patients ( 2 with severe disease) who switched to $20 \mu \mathrm{g} / \mathrm{kg}$ romiplostim, 7 (70\%) achieved neutrophil, erythroid, or platelet responses, including one complete response, after median follow-up of 12 months. ${ }^{136}$

To explain why patients with severe aplastic anemia despite paradoxically high endogenous TPO levels are pancytopenic, it has been suggested that endogenous TPO forms a heterodimer with IFN- $\gamma$, preventing the TPO-R from heterodimerizing. ${ }^{137}$ Specifically, IFN- $\gamma$ is thought to bind to TPO and thus impair it from fully engaging the MPL receptor by disrupting the low-affinity binding site in a dose-dependent manner. ${ }^{138}$ Eltrombopag does not interact with IFN- $\gamma$, but it binds to the TPO-R at a location distinct from the extracellular TPO binding site; thus, it is able to at least partially activate MPL signaling even in the presence of IFN- $\gamma \cdot{ }^{138-140}$ In theory, because romiplostim binds to the endogenous TPO site, it might not overcome the IFN- $\gamma$-mediated stem cell suppression resulting from TPO and IFN- $\gamma$ heterodimer formation. ${ }^{141}$ However, given that romiplostim has been shown to be clinically effective in signaling through the TPO-R in the high-IFN- $\gamma$ state of severe aplastic anemia, romiplostim may either stoichiometrically overcome IFN- $\gamma$ inhibition of endogenous TPO or else its mechanism is not affected by IFN- $\gamma$. Clarifying this mechanistic information will be useful to better understand its role in aplastic anemia.

\section{Acute Radiation Syndrome}

Romiplostim has been examined in mouse and macaque monkey models of acute radiation syndrome. ${ }^{142-147}$ In a cell culture model, romiplostim in combination with IL-3 or IL-3 plus stem cell factor showed a strong regenerative effect on cell proliferation, megakaryopoiesis, thrombopoiesis, and megakaryocyte colony formation from X-irradiated CD34+ cells. ${ }^{146}$ In mice subjected to total body irradiation at $70 \%$ lethal dose after 30 days, a single $30-\mu \mathrm{g} / \mathrm{kg}$ dose of romiplostim administered 24 hours after irradiation improved survival by $40 \%(57 \%$ versus $17 \%$ for control). ${ }^{142}$ Similarly, Yamaguchi et al found that a $50-\mu \mathrm{g} / \mathrm{kg}$ romiplostim dose administered on 3 consecutive days starting within 2 hours of irradiation achieved complete rescue of mice exposed to lethal gamma irradiation. ${ }^{143}$ They proposed that the ability of romiplostim to reduce lethality and pancytopenia may be due to multiple mechanisms, including stimulation of splenic progenitor cells, induction of pulmonary megakaryocytopoiesis, prevention of bone marrow cell death, modulation of DNA repair, and production of cytokines.

Romiplostim has also been examined in combination with granulocyte colony-stimulating factor and recombinant 
human erythropoietin in irradiated mice, which led to $100 \%$ survival at day $30 .{ }^{145}$ A study in a rhesus macaque model of acute radiation syndrome found that romiplostim alone or in combination with pegfilgrastim prevented severe thrombocytopenia and had other hematologic benefits. ${ }^{147}$ Rhesus macaques were given a uniform dose of 550 cGy 24 hours before administration of saline (control), romiplostim, pegfilgrastim, or a combination of both. All animals showed clinical symptoms of acute radiation syndrome, including diarrhea, decreased appetite, hunched back, and petechiae, as well as significant reductions in neutrophils and platelets. Treatment with romiplostim or pegfilgrastim or both was associated with significantly improved survival compared with controls and reduced incidence of hunched back and petechiae. Neutrophils began decreasing 3 to 5 days postirradiation in all groups and recovered most rapidly in those receiving pegfilgrastim (with or without romiplostim). In contrast, platelet counts declined beginning on day 5 postirradiation but were overall less severe among the animals treated with romiplostim. The combination of romiplostim and pegfilgrastim resulted in the least severe thrombocytopenia and earliest recovery. ${ }^{147}$

\section{Perisurgical}

Romiplostim has been used successfully to increase platelet counts in patients with thrombocytopenia caused by different underlying pathologic conditions in association with various surgical procedures. ${ }^{148-151}$ The underlying causes of thrombocytopenia included ITP, chronic liver disease, hematologic malignancy, and drug-related and hereditary causes. Retrospective data indicate that romiplostim can also improve platelet counts to levels conducive for performing various surgeries, including major cardiac, orthopedic, gastrointestinal, and neurologic surgeries. ${ }^{148,149}$ In an early study, the median starting dose of romiplostim was $2.5 \mu \mathrm{g} / \mathrm{kg}$; the median dose at the time of surgery was $3 \mu \mathrm{g} / \mathrm{kg}$ per week, with treatment starting approximately 4 weeks before surgery. ${ }^{149}$ In a more recent study, the median starting dose of romiplostim was $3.0 \mu \mathrm{g} / \mathrm{kg}$ per week, and the median time to peak preoperative platelet count was 19 days. ${ }^{148}$ Bleeding was infrequent, and most patients were able to continue with surgery on time and avoid platelet transfusions. ${ }^{148,149}$ In the first randomized trial of perioperative management of ITP, eltrombopag was noninferior to intravenous immunoglobulin in terms of achieving and maintaining target platelet counts during the perioperative period. ${ }^{152}$ However, it should be noted that for both romiplostim and eltrombopag, the amount of time needed before surgery to increase platelet counts could be problematic if a patient requires a procedure on a more immediate basis. The best treatment approaches under such circumstances (ie, TPO-RA versus intravenous immunoglobulin, dose, and timing of treatment) have been raised for the use of eltrombopag before and after surgery ${ }^{153}$ and also need further consideration for romiplostim.

\section{Posttransplant}

Virtually all patients who undergo HSCT develop pancytopenia after the conditioning regimen, and persistent thrombocytopenia frequently occurs during the posttransplant course because platelets are the last blood component to recover. In certain patients, this thrombocytopenia never resolves (primary thrombocytopenia); in others, it resolves, but then recurs (secondary thrombocytopenia). Primary persistent thrombocytopenia is most prevalent with a cord blood transplant. Multiple causes contribute to post-HSCT secondary thrombocytopenia, after engraftment of megakaryocytes and achievement of an adequate platelet count, including decreased production and increased destruction, which may coexist. ${ }^{154-156}$ Decreased production may be due to myelotoxicity of the conditioning regimen, poor graft function, rejection, graft versus marrow immunologic dysregulation (as a pattern of graft-versus-host disease), stromal damage, and viral reactivation. Increased platelet destruction is most often due to transplant-related microangiopathy, belonging to the umbrella of endothelial inflammatory diseases, which coincide to cause posttransplant thrombocytopenia. ${ }^{157}$

Thrombocytopenia post-HSCT can occur from secondary failure of platelet recovery, defined as a decline in platelet counts to below $20 \times 10^{9} / \mathrm{L}$ for 7 consecutive days or requiring transfusion support within 7 days after achieving platelet counts $\geq 50 \times 10^{9} /$ L. $^{158}$ Long-lasting thrombocytopenia could lead to potentially lethal bleeding, thus necessitating the use of prophylactic or therapeutic platelet transfusions. A delayed platelet recovery has been associated with worse transplant outcomes. ${ }^{159-161}$ Currently, there is a lack of proven effective and reliable methods to promote platelet engraftment and to prevent hemorrhagic complications and platelet transfusion needs.

Early in the post-HSCT course, patients often undergo multiple preemptive platelet transfusions to prevent bleeding complications. When engraftment is delayed, the use of a TPO mimetic may successfully increase platelet 
counts. The response rate is significantly lower in patients with a decreased number of megakaryocytes before treatment. ${ }^{162}$ No large prospective definitive studies have yet been reported. A few pilot and retrospective studies have suggested that romiplostim may be effective for improving platelet counts after $\mathrm{HSCT}^{163-165}$ In two small patient series, response to romiplostim was shown following HSCT in two of three patients ${ }^{166}$ and in six of eight patients. ${ }^{167}$ In a larger series, $100 \%$ of 20 patients treated with romiplostim achieved platelet engraftment at a median of 45 days following umbilical cord blood transplant compared with $85 \%$ of historical controls. ${ }^{168}$

The Spanish Group of HSCT retrospectively evaluated the safety and efficacy of TPO-RAs, either romiplostim or eltrombopag, in 86 patients with posttransplant thrombocytopenia. ${ }^{162}$ The overall response rate for platelet recovery $\geq 50 \times 10^{9} / \mathrm{L}$ was $72 \%$ (median [range] response at 66 [2-247] days; median [range] treatment duration 62 [7-700] days), which was sustained in $81 \%$ of the responding patients after treatment discontinuation. ${ }^{162}$ A prospective French phase $1 / 2$ study enrolled 24 patients (10 with primary and 14 with secondary thrombocytopenia) providing weekly treatment with romiplostim (starting dose $1 \mu \mathrm{g} / \mathrm{kg}$, escalating up to a maximum dose of $10 \mu \mathrm{g} /$ $\mathrm{kg}) .{ }^{169}$ Response, defined as platelet count $>50 \times 10^{9} / \mathrm{L}$ free of platelet transfusion, was achieved in 18 patients at a median (interquartile range [IQR]) time of 45 (29-41) days (range, 21-77 days), with a median (IQR) dose of 5 (4-6.8) $\mu \mathrm{g} / \mathrm{kg}$ (range, $1-11 \mu \mathrm{g} / \mathrm{kg}$ ); such a response was sustained in $16 / 18$ patients for $\geq 8$ consecutive weeks, independent of platelet transfusions. ${ }^{169}$ Mahat et al ${ }^{170}$ reviewed 12 studies (six case series and six case reports) involving the use of romiplostim for prolonged post-HSCT thrombocytopenia (primary thrombocytopenia in 17 patients and secondary in 32 patients); a platelet response of $>50 \times 10^{9} / \mathrm{L}$ free of platelet transfusion was observed in 40 out of the 49 patients $(82 \%)$ overall.

There is less experience in children. ${ }^{171-175}$ In particular, an Italian retrospective study recently reported on the use of eltrombopag in nine pediatric patients after HSCT; after a median treatment time of 36 days, eight of the nine patients $(88 \%)$ achieved sustained platelet counts $>50 \times$ $10^{9} / \mathrm{L}^{173}$ In seven children with secondary failure of platelet recovery treated with romiplostim, six $(86 \%)$ became transfusion-independent in the second week of treatment. $^{174}$

These studies suggest romiplostim could be safely administered to patients with transfusion-dependent thrombocytopenia after allogeneic HSCT and may improve platelet counts. This is particularly relevant in the posttransplant setting when the risk of hemorrhagic events is often increased by diffuse endothelial damage. Whether treatment with romiplostim increases platelet counts and facilitates a bleeding-free window to allow spontaneous platelet recovery or in some way permanently increases the platelet count still needs to be assessed. The latter appears likely, however, in a number of the cases discussed previously.

In the setting of poor engraftment, which is characterized by persistently low platelet counts, often with trilineage involvement, and a hypocellular bone marrow examination, a stem cell boost of CD34+ selection of cells from the donor, also referred to as "top-up" transfusion, may be useful. The use of TPO-RA may allow additional time to delay the second graft request from donors and possibly observe platelet recovery without it.

Prospective studies are warranted to further investigate the role romiplostim may have in this setting. Post-HSCT complications, possibly contributing to thrombocytopenia, should be accounted for to properly assess the role of TPO-RA posttransplantation.

\section{Other Settings}

Experience with romiplostim in patients with inherited thrombocytopenia, such as myosin heavy chain 9-related disease (MYH9-RD) ${ }^{176,177}$ and cases in which thrombopoietin mutation causes marked thrombocytopenia, ${ }^{178,179}$ is limited to case reports. Eltrombopag showed efficacy in 11 of 12 patients with MYH9-RD. ${ }^{180}$ Major responses were observed in eight patients $(67 \%)$ and minor responses in three patients $(25 \%)$. A more recent phase 2 study explored the effect of eltrombopag in 23 evaluable patients with expanded types of inherited thrombocytopenia (ie, MYH9-RD, ankyrin repeat domain-containing protein 26 [ANKRD26]-related thrombocytopenia, Wiskott-Aldrich syndrome/X-linked thrombocytopenia, monoallelic Bernard-Soulier syndrome, or integrin beta-3 [ITGB3]related thrombocytopenia). All but two patients $(8.7 \%)$ (ANKRD26-RT, $n=1$; ITGB3-RT, $n=1$ ) responded to treatment. $^{181}$

There are no published studies on the use of romiplostim in patients with Wiskott-Aldrich syndrome/X-linked thrombocytopenia, ${ }^{182}$ although anecdotal data suggest efficacy in five unreported cases, two from New York and three from Paris (personal communication). A recent case report of an atypical presentation of Wiskott-Aldrich 
syndrome in an infant included the use of romiplostim and platelet transfusions to maintain platelet counts. ${ }^{183}$ In a study of nine patients with Wiskott-Aldrich syndrome/ $\mathrm{X}$-linked thrombocytopenia, treatment with eltrombopag was found to be associated with beneficial effects on platelet count. ${ }^{184}$ The study also found that platelet function and ability to be activated appeared to be relatively normal, and the increased bleeding tendency at a given platelet count was thought to be due to microthrombocytopenia rather than to intrinsic platelet abnormalities. ${ }^{184}$ One patient in this study discontinued eltrombopag because of lack of response and switched to romiplostim and experienced a greater increase in platelet count and less bleeding. ${ }^{184}$

Patients with chronic liver disease often have thrombocytopenia, particularly those with cirrhosis. ${ }^{185}$ In patients with advanced chronic liver disease, TPO declines as a result of splenomegaly and hepatic damage such that the liver cannot make even normal amounts of TPO. In the settings of accelerated platelet destruction and reduced platelet production, which are typical of advanced liver disease, this contributes substantially to the degree of thrombocytopenia. ${ }^{151,185}$ Two TPO agents, avatrombopag and lusutrombopag, have been approved in the United States specifically to increase the platelet count in patients with thrombocytopenia and liver disease undergoing a procedure; ${ }^{186,187}$ eltrombopag was previously approved to treat thrombocytopenia in patients with hepatitis $\mathrm{C}$ with liver disease to allow for the initiation and maintenance of interferon-based therapy. ${ }^{129}$ Treatment with romiplostim was shown to improve platelet counts in a patient with hepatocellular carcinoma ${ }^{188}$ and in patients with hepatitis $\mathrm{C}$ virus, ${ }^{151}$ allowing most of these patients to undergo planned surgical procedures. In a case report of two patients with hepatitis C-related cirrhosis, treatment with romiplostim increased platelet counts and allowed the patients to complete an antihepatitis $\mathrm{C}$ protocol without dose delay or reduction, resulting in a sustained virologic response. ${ }^{189}$

A careful and thorough evaluation should be given before use of TPO-RAs in patients with thrombocytopenia and myelodysplastic syndrome (MDS) experiencing bleeding and requiring platelet transfusion. Several large randomized studies have been completed with both romiplostim and eltrombopag in patients with thrombocytopenia and MDS. Although neither romiplostim nor eltrombopag is approved for patients with MDS, treatment may improve platelet counts and reduce bleeding in a number of patients. ${ }^{190}$ In one of the first of these studies, treatment with romiplostim compared with placebo initially was thought to increase leukemic blast levels in blood. The study was stopped because of the increase in blasts attributed to functional TPO-R on the cells. Although these initial concerns regarding the association of treatment with leukemic progression existed, ${ }^{190-192}$ long-term follow-up of patients with MDS treated with romiplostim revealed no significant increases in the risk of acute myeloid leukemia or death. ${ }^{193}$ Additional studies further explored the risk/benefit profile of romiplostim for the treatment of MDS; ${ }^{191,194}$ however, concern for the risk of progression to leukemia has resulted in few trials in progress for this indication. ${ }^{195-197}$ The initial study, with concern for increased blasts, was in patients with a low risk for MDS also being treated with decitabine, ${ }^{198}$ whereas a later study in patients receiving romiplostim alone did not see this effect. ${ }^{199}$ Currently, TPO agents can increase platelet counts, reduce bleeding, and decrease the need for platelet transfusions in certain populations of patients with MDS. However, even in the patients who achieve these responses, an extension of survival has not been shown.

\section{Practical Treatment Considerations}

Route of administration needs to be considered when choosing a TPO-RA. When patients are starting treatment, more frequent office visits are required until platelet counts are stabilized. Romiplostim administered by weekly subcutaneous injections ${ }^{5}$ will result in such monitoring. Subsequently, the need for weekly injection may be a drawback. Home self-injections (available outside the US) may be an option for some patients and increase compliance, although some patients may prefer receiving treatment in an office by a healthcare professional.

Patients may often prefer oral TPO-RAs depending on the agent. ${ }^{3}$ Avatrombopag, lusutrombopag (liver disease only), and eltrombopag are approved for oral administration. ${ }^{129,186,187}$ Eltrombopag needs to be taken on an empty stomach ( $\geq 2$ hours before or 4 hours after calcium-rich foods) and may not be suitable in patients with absorption problems, nausea, transaminitis, or irregular mealtimes. ${ }^{3,129}$ Avatrombopag should be taken with food but does not have any dietary restrictions, and lusutrombopag can be taken with or without food. ${ }^{186,187,200}$

Discontinuation of romiplostim should be done in a stepwise fashion, as abruptly stopping treatment can lead to rebound thrombocytopenia in patients who 
responded to treatment. ${ }^{5,6,201}$ Platelet counts should be monitored at least weekly and for $\geq 2$ weeks after discontinuation. ${ }^{5,6}$ Additional therapy should be started if needed. The dose of romiplostim should be increased $1 \mu \mathrm{g} /$ $\mathrm{kg} /$ week if platelet counts decrease to $<50 \times 10^{9} / \mathrm{L}$ or the patient exhibits symptoms. 5,6,201

\section{Discussion and Conclusions}

Thrombopoietin is involved in multiple steps of platelet production, from the stem cell through development of mature megakaryocytes and possibly even platelet release. ${ }^{10,11}$ Romiplostim is an important TPO-RA that has advanced treatment options for individuals with thrombocytopenia and acts by increasing platelet production and therefore increasing platelet counts. Increased platelet counts can reduce the need for platelet transfusions and decrease bleeding events in multiple conditions. ${ }^{61-64}$ Romiplostim binds to and activates the TPO-R on megakaryocyte precursors, ${ }^{58}$ activating multiple cell-signaling pathways, leading to enhanced cell growth and cell viability, which results in increased platelet production. ${ }^{3,59,68}$ Although there are ample data on the use of romiplostim in adults and children with chronic ITP, evolving data on romiplostim in newly diagnosed patients with ITP shows its potential use as early treatment for adults who do not respond to corticosteroids. Furthermore, there is potential for either long-term or treatment-free responses in these patients with early-stage disease. The approval for romiplostim by the US Food and Drug Administration (but not EMA) was recently extended to cover this early use. ${ }^{5}$ Studies have also shown romiplostim to be effective in improving platelet counts in various preclinical and clinical settings, including CIT, aplastic anemia, animal models of acute radiation syndrome, and liver disease. Although none of these indications have been approved yet in the United States, these studies highlight the versatility of romiplostim in thrombocytopenic conditions other than ITP. In particular, in severe aplastic anemia, for which eltrombopag has been licensed as upfront treatment in combination with standard immunosuppressive therapy, a recent study showed similar efficacy of romiplostim. ${ }^{18}$ The safety and efficacy of romiplostim has led to anecdotal use in both primary and secondary thrombocytopenia in the post-HSCT setting, where response to treatment eventually allows prevention of bleeding and differentiation of thrombocytopenia caused by concomitant postHSCT-specific complications. Although romiplostim cannot be recommended for use in unapproved clinical conditions, such as MDS or in other non-ITP patient populations, a positive risk/benefit profile has been established for the treatment of thrombocytopenia associated with chronic ITP. Future studies may expand this approval profile.

\section{Abbreviations}

ANKRD26, ankyrin repeat domain-containing protein 26; CIT, chemotherapy-induced thrombocytopenia; Fc, fragment crystallizable; HSCT, hematopoietic stem cell transplant; IFN- $\gamma$, interferon- $\gamma$; IL, interleukin; IQR, interquartile range; ITGB3, integrin beta-3; ITP, immune thrombocytopenia; MDS, myelodysplastic syndrome; MHCII, major histocompatibility complex class II; MPL, myeloproliferative leukemia virus; MYH9-RD, myosin heavy chain 9-related disease; Th1, type 1 T-helper; Th17, type 17 T-helper; TPO, thrombopoietin; TPO-R, thrombopoietin receptor; TPO-RA, thrombopoietin receptor agonist; Treg, regulatory T-cell.

\section{Acknowledgments}

This work was supported by Amgen Inc., Thousand Oaks, CA, USA. Miranda Tradewell, PhD, and Maryann Travaglini, PharmD, ICON (North Wales, PA, USA), provided medical writing support with funding from Amgen Inc.

\section{Disclosure}

James B Bussel has participated in advisory boards and received consultancy fees from Amgen Inc., Argenx, CSLBehring, Dova Pharmaceuticals, Kezar, Momenta-J \& J, Novartis, Principia, Regeneron, Rigel, and UCB; has participated in speakers bureaus with Novartis and 3S Bio; and has received honoraria from Up to Date. Gerald Soff has received research support from Amgen, Dova Pharmaceuticals, and Janssen Scientific Affairs; has participated in advisory boards and received consultancy fees from Amgen, Anthos Therapeutics, Bayer Pharmaceuticals, Bristol Myers Squibb, Dova Pharmaceuticals, Hengrui (USA) Ltd, Janssen Scientific Affairs, Novartis, and Pfizer; and has received honoraria from Amgen and Bayer Pharmaceuticals. Nichola Cooper has received honoraria for speaking engagements and participated in advisory boards with Amgen, Novartis, Principia, and Rigel; and has received support for clinical trials from Amgen, Novartis, Rigel, Principia, and UCB. 
Tatiana Lawrence is an employee and stockholder of Amgen. Adriana Balduzzi has received honoraria, advisory board, lectures, speakers bureaus, and/or meeting/ travel assistance from Amgen, Novartis, Medac, and Neovii, outside the submitted work. The authors report no other conflicts of interest in this work.

\section{References}

1. Bussel J, Kulasekararaj A, Cooper N, et al. Mechanisms and therapeutic prospects of thrombopoietin receptor agonists. Semin Hematol. 2019;56(4):262-278. doi:10.1053/j.seminhematol.2019. 09.001

2. Kaushansky K. The molecular mechanisms that control thrombopoiesis. $J$ Clin Invest. 2005;115(12):3339-3347. doi:10. 1172/JCI26674

3. Ghanima W, Cooper N, Rodeghiero F, Godeau B, Bussel JB. Thrombopoietin receptor agonists: ten years later. Haematologica. 2019;104(6):1112-1123. doi:10.3324/haematol.2018.212845

4. Kuter DJ. New thrombopoietic growth factors. Clin Lymphoma Myeloma. 2009;9:S347-S356. doi:10.3816/CLM.2009.s.034

5. Nplate ${ }^{\mathbb{R}}$. Romiplostim. Thousand Oaks, CA: Amgen Inc.; 2019.

6. EMA. European Medicines Agency. Romiplostim summary of product characteristics. Available from: https://ec.europa.eu/ health/documents/community-register/2021/20210122150420/ anx_150420_en.pdf. Accessed April 15, 2021.

7. Kuter DJ, Begley CG. Recombinant human thrombopoietin: basic biology and evaluation of clinical studies. Blood. 2002;100 (10):3457-3469. doi:10.1182/blood.V100.10.3457

8. Kato T, Matsumoto A, Ogami K, Tahara T, Morita H, Miyazaki H. Native thrombopoietin: structure and function. Stem Cell. 1998;16(5):322-328. doi:10.1002/stem.160322

9. Kuter DJ. Milestones in understanding platelet production: a historical overview. Br J Haematol. 2014;165(2):248-258. doi:10.1111/bjh.12781

10. Kaushansky K. Thrombopoietin. $N$ Engl J Med. 1998;339 (11):746-754. doi:10.1056/NEJM199809103391107

11. Nakamura-Ishizu A, Suda T. Multifaceted roles of thrombopoietin in hematopoietic stem cell regulation. Ann N Y Acad Sci. 2020;1466(1):51-58. doi:10.1111/nyas.14169

12. Kaushansky K, Lok S, Holly RD, et al. Promotion of megakaryocyte progenitor expansion and differentiation by the c-Mpl ligand thrombopoietin. Nature. 1994;369(6481):568-571. doi:10. 1038/369568a0

13. Kuter DJ, Beeler DL, Rosenberg RD. The purification of megapoietin: a physiological regulator of megakaryocyte growth and platelet production. Proc Natl Acad Sci U S A. 1994;91 (23):11104-11108. doi:10.1073/pnas.91.23.11104

14. Broudy VC, Lin NL, Kaushansky K. Thrombopoietin (c-mpl ligand) acts synergistically with erythropoietin, stem cell factor, and interleukin-11 to enhance murine megakaryocyte colony growth and increases megakaryocyte ploidy in vitro. Blood. 1995;85 (7):1719-1726. doi:10.1182/blood.V85.7.1719.bloodjournal8571 719

15. Ku H, Yonemura Y, Kaushansky K, Ogawa M. Thrombopoietin, the ligand for the Mpl receptor, synergizes with steel factor and other early acting cytokines in supporting proliferation of primitive hematopoietic progenitors of mice. Blood. 1996;87(11):4544-4551. doi:10.1182/blood.V87.11.4544.bloodjournal 87114544

16. Rasko JE, O'Flaherty E, Begley CG. Mpl ligand (MGDF) alone and in combination with stem cell factor (SCF) promotes proliferation and survival of human megakaryocyte, erythroid and granulocyte/macrophage progenitors. Stem Cell. 1997;15 (1):33-42. doi:10.1002/stem.150033
17. Sitnicka E, Lin N, Priestley GV, et al. The effect of thrombopoietin on the proliferation and differentiation of murine hematopoietic stem cells. Blood. 1996;87(12):4998-5005. doi:10.1182/blood. V87.12.4998.bloodjournal87124998

18. Lee JW, Lee SE, Jung CW, et al. Romiplostim in patients with refractory aplastic anaemia previously treated with immunosuppressive therapy: a dose-finding and long-term treatment phase 2 trial. Lancet Haematol. 2019;6(11):e562-e572. doi:10.1016/ S2352-3026(19)30153-X

19. Ishikawa M, Matsuda A, Okamura D, et al. The progression of severe aplastic anemia to hypoplastic leukemia in a long-term observation after the administration of pegylated rHuMGDF. Hematol Rep. 2018;10(3):7679. doi:10.4081/hr.2018.7679

20. de Laval B, Pawlikowska P, Barbieri D, et al. Thrombopoietin promotes NHEJ DNA repair in hematopoietic stem cells through specific activation of Erk and NF-kappaB pathways and their target, IEX-1. Blood. 2014;123(4):509-519. doi:10.1182/blood-2013-07-515874

21. Mitchell WB, Pinheiro MP, Boulad N, et al. Effect of thrombopoietin receptor agonists on the apoptotic profile of platelets in patients with chronic immune thrombocytopenia. Am J Hematol. 2014;89(12):E228-E234. doi:10.1002/ajh.23832

22. Branehog I, Weinfeld A. Platelet survival and platelet production in idiopathic thrombocytopenic purpura (ITP) before and during treatment with corticosteroids. Scand J Haematol. 2009;12 (1):69-79. doi:10.1111/j.1600-0609.1974.tb00182.x

23. Chang M, Nakagawa PA, Williams SA, et al. Immune thrombocytopenic purpura (ITP) plasma and purified ITP monoclonal autoantibodies inhibit megakaryocytopoiesis in vitro. Blood. 2003;102(3):887-895. doi:10.1182/blood-2002-05-1475

24. Ballem PJ, Segal GM, Stratton JR, Gernsheimer T, Adamson JW, Slichter SJ. Mechanisms of thrombocytopenia in chronic autoimmune thrombocytopenic purpura. Evidence of both impaired platelet production and increased platelet clearance. $J$ Clin Invest. 1987;80(1):33-40. doi:10.1172/JCI113060

25. McMillan R, Wang L, Tomer A, Nichol J, Pistillo J. Suppression of in vitro megakaryocyte production by antiplatelet autoantibodies from adult patients with chronic ITP. Blood. 2004;103 (4):1364-1369. doi:10.1182/blood-2003-08-26722003-08-2672

26. Cooper N, Ghanima W. Immune thrombocytopenia. $N$ Engl $J$ Med. 2019;381(10):945-955. doi:10.1056/NEJMcp1810479

27. Lev PR, Grodzielski M, Goette NP, et al. Impaired proplatelet formation in immune thrombocytopenia: a novel mechanism contributing to decreased platelet count. Br J Haematol. 2014;165 (6):854-864. doi:10.1111/bjh.12832

28. Iraqi M, Perdomo J, Yan F, Choi PY, Chong BH. Immune thrombocytopenia: antiplatelet autoantibodies inhibit proplatelet formation by megakaryocytes and impair platelet production in vitro. Haematologica. 2015;100(5):623-632. doi:10.3324/haematol.20 14.115634

29. van Leeuwen EF, van der Ven JT, Engelfriet CP, von Dem Borne AE. Specificity of autoantibodies in autoimmune thrombocytopenia. Blood. 1982;59(1):23-26. doi:10.1182/blood. V59.1.23.23

30. Najaoui A, Bakchoul T, Stoy J, et al. Autoantibody-mediated complement activation on platelets is a common finding in patients with immune thrombocytopenic purpura (ITP). Eur J Haematol. 2012;88 (2):167-174. doi:10.1111/j.1600-0609.2011.01718.x

31. Gernsheimer T, Stratton J, Ballem PJ, Slichter SJ. Mechanisms of response to treatment in autoimmune thrombocytopenic purpura. $N$ Engl J Med. 1989;320(15):974-980. doi:10.1056/NEJM1989 04133201505

32. Norris PAA, Segel GB, Burack WR, et al. FegammaRI and FcgammaRIII on splenic macrophages mediate phagocytosis of anti-glycoprotein IIb/IIIa autoantibody-opsonized platelets in immune thrombocytopenia. Haematologica. 2020;106(1):25 0-254. doi:10.3324/haematol.2020.248385 
33. Rocha AM, Souza C, Rocha GA, et al. The levels of IL-17A and of the cytokines involved in Th17 cell commitment are increased in patients with chronic immune thrombocytopenia. Haematologica. 2011;96 (10):1560-1564. doi:10.3324/haematol.2011.046417

34. Rocha AM, Souza C, Rocha GA, et al. The serum levels of the cytokines involved in the Th17 and Th1 cell commitment are increased in individuals with borderline thrombocytopenia. $J$ Hematol Oncol. 2013;6:28. doi:10.1186/1756-8722-6-28

35. Stasi R, Cooper N, Del Poeta G, et al. Analysis of regulatory T-cell changes in patients with idiopathic thrombocytopenic purpura receiving $\mathrm{B}$ cell-depleting therapy with rituximab. Blood. 2008;112(4):1147-1150. doi:10.1182/blood-2007-12-129262

36. Zhang F, Chu X, Wang L, et al. Cell-mediated lysis of autologous platelets in chronic idiopathic thrombocytopenic purpura. Eur J Haematol. 2006;76(5):427-431. doi:10.1111/j.1600-0609.2005.00 622.x

37. Takahashi R, Sekine N, Nakatake T. Influence of monoclonal antiplatelet glycoprotein antibodies on in vitro human megakaryocyte colony formation and proplatelet formation. Blood. 1999;93(6):1951-1958. doi:10.1182/blood.V93.6.1951.406a33_1 $951 \_1958$

38. Hoffman R, Zaknoen S, Yang HH, et al. An antibody cytotoxic to megakaryocyte progenitor cells in a patient with immune thrombocytopenic purpura. $N$ Engl J Med. 1985;312(18):1170-1174. doi:10.1056/NEJM198505023121807

39. Semple JW, Milev Y, Cosgrave D, et al. Differences in serum cytokine levels in acute and chronic autoimmune thrombocytopenic purpura: relationship to platelet phenotype and antiplatelet T-cell reactivity. Blood. 1996;87(10):4245-4254. doi:10.1182/ blood.V87.10.4245.bloodjournal87104245

40. Porcelijn L, Huiskes E, Oldert G, Schipperus M, Zwaginga JJ, de Haas M. Detection of platelet autoantibodies to identify immune thrombocytopenia: state of the art. Br J Haematol. 2018;182 (3):423-426. doi:10.1111/bjh.15404

41. Newland A, Lee EJ, McDonald V, Bussel JB. Fostamatinib for persistent/chronic adult immune thrombocytopenia. Immunotherapy. 2018;10(1):9-25. doi:10.2217/imt-2017-0097

42. Teraz-Orosz A, Cooper N, Crawley JTB, Salles C II. Detection of anti-platelet antibodies in immune thrombocytopenia by flow cytometry. Br J Haematol. 2019;184(5):844-847. doi:10.1111/ bjh. 15187

43. Li S, Wang L, Zhao C, Li L, Peng J, Hou M. CD8+ T cells suppress autologous megakaryocyte apoptosis in idiopathic thrombocytopenic purpura. $B r \quad J$ Haematol. 2007;139 (4):605-611. doi:10.1111/j.1365-2141.2007.06737.x

44. Olsson B, Andersson PO, Jernas M, et al. T-cell-mediated cytotoxicity toward platelets in chronic idiopathic thrombocytopenic purpura. Nat Med. 2003;9(9):1123-1124. doi:10.1038/ nm921

45. Chapman LM, Aggrey AA, Field DJ, et al. Platelets present antigen in the context of MHC class I. J Immunol. 2012;189 (2):916-923. doi:10.4049/jimmunol.1200580

46. Zufferey A, Speck ER, Machlus KR, et al. Mature murine megakaryocytes present antigen-MHC class I molecules to T cells and transfer them to platelets. Blood Adv. 2017;1(20):1773-1785. doi:10.1182/bloodadvances.2017007021

47. Peerschke EI, Panicker S, Bussel J. Classical complement pathway activation in immune thrombocytopenia purpura: inhibition by a novel C1s inhibitor. Br J Haematol. 2016;173(6):942-945. doi: $10.1111 /$ bjh. 13648

48. Mason KD, Carpinelli MR, Fletcher JI, et al. Programmed anuclear cell death delimits platelet life span. Cell. 2007;128 (6):1173-1186. doi:10.1016/j.cell.2007.01.037

49. Quach ME, Chen W, Li R. Mechanisms of platelet clearance and translation to improve platelet storage. Blood. 2018;131 (14):1512-1521. doi:10.1182/blood-2017-08-743229
50. Qiao J, Liu Y, Li D, et al. Imbalanced expression of Bcl-xL and Bax in platelets treated with plasma from immune thrombocytopenia. Immunol Res. 2016;64(2):604-609. doi:10.10 07/s12026-015-8760-z

51. Kuwana M, Okazaki Y, Ikeda. Detection of circulating B cells producing anti-GPIb autoantibodies in patients with immune thrombocytopenia. PLoS One. 2014;9(1):e86943. doi:10.1371/ journal.pone.0086943

52. Grozovsky R, Begonja AJ, Liu K, et al. The Ashwell-Morell receptor regulates hepatic thrombopoietin production via JAK2-STAT3 signaling. Nat Med. 2015;21(1):47-54. doi:10.10 38/nm.3770

53. Leven RM, Clark B, Tablin F. Effect of recombinant interleukin-6 and thrombopoietin on isolated guinea pig bone marrow megakaryocyte protein phosphorylation and proplatelet formation. Blood Cells Mol Dis. 1997;23(2):252-268. doi:10.1006/bcmd.1997.0142

54. Kaser A, Brandacher G, Steurer W, et al. Interleukin-6 stimulates thrombopoiesis through thrombopoietin: role in inflammatory thrombocytosis. Blood. 2001;98(9):2720-2725. doi:10.1182/ blood.v98.9.2720

55. Eulenfeld R, Dittrich A, Khouri C, et al. Interleukin-6 signalling: more than Jaks and STATs. Eur J Cell Biol. 2012;91 (6-7):486-495. doi:10.1016/j.ejcb.2011.09.010

56. Grozovsky R, Giannini S, Falet H, Hoffmeister KM. Regulating billions of blood platelets: glycans and beyond. Blood. 2015;126(16):1877-1884. doi:10.1182/blood-2015-01569129

57. Cwirla SE, Balasubramanian P, Duffin DJ, et al. Peptide agonist of the thrombopoietin receptor as potent as the natural cytokine. Science. 1997;276(5319):1696-1699. doi:10.1126/science.276.5319.1696

58. Wang B, Nichol JL, Sullivan JT. Pharmacodynamics and pharmacokinetics of AMG 531, a novel thrombopoietin receptor ligand. Clin Pharmacol Ther. 2004;76(6):628-638. doi:10.1016/j. clpt.2004.08.010

59. Broudy VC, Lin NL. AMG531 stimulates megakaryopoiesis in vitro by binding to Mpl. Cytokine. 2004;25(2):52-60.

60. Kuter DJ. The biology of thrombopoietin and thrombopoietin receptor agonists. Int J Hematol. 2013;98(1):10-23. doi:10.10 07/s12185-013-1382-0

61. Bussel JB, Kuter DJ, George JN, et al. AMG 531, a thrombopoiesis-stimulating protein, for chronic ITP. $N$ Engl $J$ Med. 2006;355(16):1672-1681. doi:10.1056/NEJMoa054626

62. Kuter DJ, Bussel JB, Lyons RM, et al. Efficacy of romiplostim in patients with chronic immune thrombocytopenic purpura: a double-blind randomised controlled trial. Lancet. 2008;371 (9610):395-403. doi:10.1016/S0140-6736(08)60203-2

63. Kuter DJ, Rummel M, Boccia R, et al. Romiplostim or standard of care in patients with immune thrombocytopenia. $N$ Engl J Med. 2010;363(20):1889-1899. doi:10.1056/NEJMoa1002625

64. Shirasugi Y, Ando K, Miyazaki K, et al. Romiplostim for the treatment of chronic immune thrombocytopenia in adult Japanese patients: a double-blind, randomized Phase III clinical trial. Int $J$ Hematol. 2011;94(1):71-80. doi:10.1007/s12185-011-0886-8

65. Bao W, Bussel JB, Heck S, et al. Improved regulatory T-cell activity in patients with chronic immune thrombocytopenia treated with thrombopoietic agents. Blood. 2010;116(22):4639-4645. doi:10.1182/blood-2010-04-281717

66. Kapur R, Aslam R, Speck ER, Rebetz JM, Semple JW. Thrombopoietin receptor agonist (TPO-RA) treatment raises platelet counts and reduces anti-platelet antibody levels in mice with immune thrombocytopenia (ITP). Platelets. 2020;31(3):399-402. doi:10.1080/09537104.2019.1624709

67. Schifferli A, Nimmerjahn F, Kühne T. Immunomodulation in primary immune thrombocytopenia: a possible role of the $\mathrm{Fc}$ fragment of romiplostim? Front Immunol. 2019;10:1196. doi:10. 3389/fimmu.2019.01196 
68. Currao M, Balduini CL, Balduini A, Lin B. High doses of romiplostim induce proliferation and reduce proplatelet formation by human megakaryocytes. PLoS One. 2013;8(1):e54723. doi:10.1371/journal.pone. 0054723

69. Roth M, Will B, Simkin G, et al. Eltrombopag inhibits the proliferation of leukemia cells via reduction of intracellular iron and induction of differentiation. Blood. 2012;120(2):386-394. doi:10.1182/blood-2011-12-399667

70. Wang YM, Krzyzanski W, Doshi S, Xiao JJ, Perez-Ruixo JJ, Chow AT. Pharmacodynamics-mediated drug disposition (PDMDD) and precursor pool lifespan model for single dose of romiplostim in healthy subjects. Validation studies. AAPS J. 2010;12(4):729-740. doi:10.1208/s12248-010-9234-9

71. Krzyzanski W, Sutjandra L, Perez-Ruixo JJ, Sloey B, Chow AT, Wang YM. Pharmacokinetic and pharmacodynamic modeling of romiplostim in animals. Pharm Res. 2013;30(3):655-669. doi:10.1007/s11095-012-0894-2

72. Newland A, Caulier MT, Kappers-Klunne M, et al. An open-label, unit dose-finding study of AMG 531, a novel thrombopoiesis-stimulating peptibody, in patients with immune thrombocytopenic purpura. $B r \quad J$ Haematol. 2006;135 (4):547-553. doi:10.1111/j.1365-2141.2006.06339.x

73. Newland A, Godeau B, Priego V, et al. Remission and platelet responses with romiplostim in primary immune thrombocytopenia: final results from a phase 2 study. Br J Haematol. 2016;172 (2):262-273. doi:10.1111/bjh.13827

74. Kuter DJ, Bussel JB, Newland A, et al. Long-term treatment with romiplostim in patients with chronic immune thrombocytopenia: safety and efficacy. $\mathrm{Br} J$ Haematol. 2013;161(3):411-423. doi:10.1111/bjh.12260

75. Bussel JB, Kuter DJ, Pullarkat V, Lyons RM, Guo M, Nichol JL. Safety and efficacy of long-term treatment with romiplostim in thrombocytopenic patients with chronic ITP. Blood. 2009;113 (10):2161-2171. doi:10.1182/blood-2008-04-150078

76. Cines DB, Wasser J, Rodeghiero F, et al. Safety and efficacy of romiplostim in splenectomized and nonsplenectomized patients with primary immune thrombocytopenia. Haematologica. 2017;102(8):1342-1351. doi:10.3324/haematol.2016.161968

77. Bussel JB, Buchanan GR, Nugent DJ, et al. A randomized, double-blind study of romiplostim to determine its safety and efficacy in children with immune thrombocytopenia. Blood. 2011;118(1):28-36. doi:10.1182/blood-2010-10-313908

78. Tarantino MD, Bussel JB, Blanchette VS, et al. Romiplostim in children with immune thrombocytopenia: a phase 3 , randomised, double-blind, placebo-controlled study. Lancet. 2016;388 (10039):45-54. doi:10.1016/s0140-6736(16)00279-8

79. Tarantino MD, Bussel JB, Blanchette VS, et al. Long-term treatment with romiplostim and treatment-free platelet responses in children with chronic immune thrombocytopenia. Haematologica. 2019;104(11):2283-2291. doi:10.3324/ haematol.2018.202283

80. Bussel JB, Hsieh L, Buchanan GR, et al. Long-term use of the thrombopoietin-mimetic romiplostim in children with severe chronic immune thrombocytopenia (ITP). Pediatr Blood Cancer. 2015;62(2):208-213. doi:10.1002/pbc.25136

81. Steurer M, Quittet P, Papadaki HA, et al. A large observational study of patients with primary immune thrombocytopenia receiving romiplostim in European clinical practice. Eur J Haematol. 2017;98(2):112-120. doi:10.1111/ejh.12807

82. Doobaree IU, Newland A, McDonald V, et al. Primary immune thrombocytopenia (ITP) treated with romiplostim in routine clinical practice: retrospective study from the United Kingdom ITP registry. Eur J Haematol. 2019;102(5):416-423. doi:10.1111/ ejh. 13221
83. Carpenedo M, Cantoni S, Coccini V, Fedele M, Morra E, Pogliani EM. Feasibility of romiplostim discontinuation in adult thrombopoietin-receptor agonist responsive patients with primary immune thrombocytopenia: an observational retrospective report in real life clinical practice. Hematol Rep. 2015;7(1):5673. doi:10.4081/hr.2015.5673

84. Cervinek L, Mayer J, Doubek M. Sustained remission of chronic immune thrombocytopenia after discontinuation of treatment with thrombopoietin-receptor agonists in adults. Int $J$ Hematol. 2015;102(1):7-11. doi:10.1007/s12185-015-1793-1

85. Ghadaki B, Nazi I, Kelton JG, Arnold DM. Sustained remissions of immune thrombocytopenia associated with the use of thrombopoietin receptor agonists. Transfusion. 2013;53(11):2807-2812. doi:10.1111/trf.12139

86. Mingot-Castellano ME, Grande-Garcia C, Valcarcel-Ferreiras D, Conill-Cortes C, de Olivar-oliver L. Sustained remission in patients with primary immune thrombocytopenia after romiplostim tapering and discontinuation: a case series in real life management in Spain. Case Rep Hematol. 2017;2017:4109605. doi:10.1155/2017/4109605

87. Lozano ML, Mingot-Castellano ME, Perera MM, et al. Deciphering predictive factors for choice of thrombopoietin receptor agonist, treatment free responses, and thrombotic events in immune thrombocytopenia. Sci Rep. 2019;9(1):16680. doi:10.1038/s41598-019-53209-y

88. Wang M, Qin P, Zhou H, et al. Recombinant human thrombopoietin (rhTPO) and high-dose dexamethasone (HD-DXM) versus high-dose dexamethasone monotherapy as frontline treatment in newly diagnosed adult immune thrombocytopenia (ITP): a prospective, multicentre, randomised, controlled trial. Blood. 2017;130(suppl 1):13. doi:10.1182/blood.V130.Suppl_1.13.13

89. Cines DB, Gernsheimer T, Wasser J, et al. Integrated analysis of long-term safety in patients with chronic immune thrombocytopaenia (ITP) treated with the thrombopoietin (TPO) receptor agonist romiplostim. Int $J$ Hematol. 2015;102(3):259-270. doi:10.1007/s12185-015-1837-6

90. Grainger J, Bussel J, Tarantino M, et al. Updated results from the single-arm, open-label, long-term efficacy and safety study of subcutaneous (SC) romiplostim in children with immune thrombocytopenia (ITP). Blood. 2019;134(Suppl1):1095. doi:10.1182/ blood-2019-131241

91. Wong RSM, Saleh MN, Khelif A, et al. Safety and efficacy of long-term treatment of chronic/persistent ITP with eltrombopag: final results of the EXTEND study. Blood. 2017;130 (23):2527-2536. doi:10.1182/blood-2017-04-748707

92. Ghanima W, Junker P, Hasselbalch HC, et al. Fibroproliferative activity in patients with immune thrombocytopenia (ITP) treated with thrombopoietic agents. $\mathrm{Br} \quad J$ Haematol. 2011;155 (2):248-255. doi:10.1111/j.1365-2141.2011.08845.x

93. Rodeghiero F, Stasi R, Giagounidis A, et al. Long-term safety and tolerability of romiplostim in patients with primary immune thrombocytopenia: a pooled analysis of 13 clinical trials. Eur J Haematol. 2013;91:423-436. doi:10.1111/ejh.12181

94. Kuter DJ, Mufti GJ, Bain BJ, Hasserjian RP, Davis W, Rutstein M. Evaluation of bone marrow reticulin formation in chronic immune thrombocytopenia patients treated with romiplostim. Blood. 2009;114(18):3748-3756. doi:10.1182/ blood-2009-05-224766

95. Lozano ML, Mingot-Castellano ME, Perera M, et al. Predictive factors for thrombopoietin receptor agonist free responses in chronic ITP patients: a multicenter retrospective study with long-term follow-up. Blood. 2019;134(suppl 1):2370. doi:10.11 82/blood-2019-125580 
96. Cuker A, Prak ET, Cines DB. Can immune thrombocytopenia be cured with medical therapy? Semin Thromb Hemost. 2015;41 (4):395-404. doi:10.1055/s-0034-1544001

97. Gómez-Almaguer D, Herrera-Rojas MA, Jaime-Pérez JC, et al. Eltrombopag and high-dose dexamethasone as frontline treatment of newly diagnosed immune thrombocytopenia in adults. Blood. 2014;123(25):3906-3908. doi:10.1182/blood-2014-01549360

98. Gudbrandsdottir S, Birgens HS, Frederiksen H, et al. Rituximab and dexamethasone vs dexamethasone monotherapy in newly diagnosed patients with primary immune thrombocytopenia. Blood. 2013;121(11):1976-1981. doi:10.1182/blood-2012-09455691

99. Zaja F, Baccarani M, Mazza P, et al. Dexamethasone plus rituximab yields higher sustained response rates than dexamethasone monotherapy in adults with primary immune thrombocytopenia. Blood. 2010;115(14):2755-2762. doi:10.1182/blood-2009-07229815

100. Newland A, Bussel JB, Bird R, et al. Predictors of remission in adults with immune thrombocytopenia (ITP) treated with romiplostim. Blood. 2018;132(Supplement 1):735. doi:10.1182/ blood-2018-99-109791

101. Bussel JB, Wang X, Lopez A, Eisen M. Case study of remission in adults with immune thrombocytopenia following cessation of treatment with the thrombopoietin mimetic romiplostim. Hematology. 2016;21(4):257-262. doi:10.1179/1607845415y.00 00000041

102. Kuter DJ, Newland A, Chong BH, et al. Romiplostim in adult patients with newly diagnosed or persistent immune thrombocytopenia (ITP) for up to 1 year and in those with chronic ITP for more than 1 year: a subgroup analysis of integrated data from completed romiplostim studies. $\mathrm{Br} J$ Haematol. 2019;185 (3):503-513. doi:10.1111/bjh.15803

103. Schifferli A, Holbro A, Chitlur M, et al. A comparative prospective observational study of children and adults with immune thrombocytopenia: 2-year follow-up. Am J Hematol. 2018;93 (6):751-759. doi:10.1002/ajh.25086

104. Kuter DJ. Managing thrombocytopenia associated with cancer chemotherapy. Oncology. 2015;29(4):282-294.

105. Weycker D, Hatfield M, Grossman A, et al. Risk and consequences of chemotherapy-induced thrombocytopenia in US clinical practice. BMC Cancer. 2019;19(1):151. doi:10.1186/s12885019-5354-5

106. Denduluri N, Patt DA, Wang Y, et al. Dose delays, dose reductions, and relative dose intensity in patients with cancer who received adjuvant or neoadjuvant chemotherapy in community oncology practices. J Natl Compr Canc Netw. 2015;13 (11):1383-1393. doi:10.6004/jnccn.2015.0166

107. Lyman GH, Dale DC, Tomita D, Whittaker S, Crawford J. A retrospective evaluation of chemotherapy dose intensity and supportive care for early-stage breast cancer in a curative setting. Breast Cancer Res Treat. 2013;139(3):863-872. doi:10.1007/ s10549-013-2582-2

108. Gernsheimer TB, Brown SB, Triulzi DJ, et al. Effects of tranexamic acid prophylaxis on bleeding outcomes in hematologic malignancy: the a-TREAT trial. Blood. 2020;136(Supplement 1):1-2. doi:10.1182/blood-2020-138920

109. McElroy PL, Wei P, Buck K, et al. Romiplostim promotes platelet recovery in a mouse model of multicycle chemotherapy-induced thrombocytopenia. Exp Hematol. 2015;43(6):479-487. doi:10. 1016/j.exphem.2015.02.004
110. Demeter J, Istenes I, Fodor A, et al. Efficacy of romiplostim in the treatment of chemotherapy induced thrombocytopenia (CIT) in a patient with mantle cell lymphoma. Case reports. Pathol Oncol Res. 2011;17(1):141-143. doi:10.1007/s12253010-9276-4

111. Jacobson AE, Shah N, Setty BA. Romiplostim for therapy-related thrombocytopenia in pediatric malignancies [Brief report] Pediatr Blood Cancer. 2017;64(8):e26473. doi:10.1002/ pbc. 26473

112. Al-Samkari H, Marshall AL, Goodarzi K, Kuter DJ. The use of romiplostim in treating chemotherapy-induced thrombocytopenia in patients with solid tumors. Haematologica. 2018;103(4):e169e172. doi:10.3324/haematol.2017.180166

113. Parameswaran R, Lunning M, Mantha S, et al. Romiplostim for management of chemotherapy-induced thrombocytopenia. Support Care Cancer. 2014;22(5):1217-1222. doi:10.1007/s00520-0132074-2

114. Dardis C, Milton K, Patel N. Thrombopoietin receptor agonists are effective in treating chemotherapy-induced thrombocytopenia in patients with gliomas undergoing myelotoxic treatment. Oncomedicine. 2017;2:37-41. doi:10.7150/oncm.17909

115. Entrena Ureña L, Fernandez Jimenez D, Mesa Morales Z, Hernandez Mohedo F, Jurado Chacon M. The role of romiplostim in chemotherapy-induced thrombocytopenia treatment. Haematologica. 2016;101:590.

116. Fanale M, Stiff P, Noonan K, McCoy J, Rutstein M, Moskowitz C. Safety of romiplostim for treatment of severe chemotherapy induced thrombocytopenia (CIT) in patients with lymphoma receiving multi-cycle chemotherapy: results from an open-label dose- and schedule-finding study. Eur J Cancer. 2009;7(2-3):563. doi:10.1016/S1359-6349(09)71900-7

117. Soff GA, Miao Y, Bendheim G, et al. Romiplostim treatment of chemotherapy-induced thrombocytopenia. J Clin Oncol. 2019;37 (31):2892-2898. doi:10.1200/JCO.18.01931

118. ClinicalTrials.gov. Study of romiplostim for chemotherapy-induced thrombocytopenia in adult subjects with non-small cell lung cancer (NSCLC), ovarian cancer, or breast cancer (NCT03937154). Available from: https://clinicaltrials.gov/ ct2/show/NCT03937154. Accessed July 9, 2019.

119. ClinicalTrials.gov. Study of romiplostim for chemotherapy induced thrombocytopenia (NCT02052882). Available from: https://clinical trials.gov/ct2/show/NCT02052882. Accessed July 9, 2019.

120. ClinicalTrials.gov. Study of romiplostim for chemo-induced thrombocytopenia in adults subjects with gastrointestinal or colorectal cancer (NCT03362177). Available from: https://clinical trials.gov/ct2/show/NCT03362177. Accessed July 26, 2019.

121. Al-Samkari H, Parnes AD, Goodarzi K, Weitzman JI, Connors JM, Kuter DJ. A multicenter study of romiplostim for chemotherapy-induced thrombocytopenia in solid tumors and hematologic malignancies. Haematologica. 2020. doi:10.3324/ haematol.2020.251900

122. Soff GA, Ray-Coquard I, Marfil-Rivera LJ, et al. Literature review of TPOR agonists for CIT [abstract 1563P]. Ann Oncol. 2017;28(suppl 5):mdx388. doi:10.1093/annonc/mdx388.023

123. Kaushansky K, Lichtman MA, Prchal JT, et al. Williams Hematology. 9th ed. McGraw-Hill; 2016.

124. Marsh JC. Bone marrow failure syndromes. Clin Med. 2005;5 (4):332-336. doi:10.7861/clinmedicine.5-4-332

125. Marsh JC, Gibson FM, Prue RL, et al. Serum thrombopoietin levels in patients with aplastic anaemia. Br J Haematol. 1996;95 (4):605-610. doi:10.1046/j.1365-2141.1996.d01-1966.x 
126. Kojima S, Matsuyama T, Kodera Y, Tahara T, Kato T. Measurement of endogenous plasma thrombopoietin in patients with acquired aplastic anaemia by a sensitive enzyme-linked immunosorbent assay. $\mathrm{Br} J$ Haematol. 1997;97(3):538-543. doi:10.1046/j.1365-2141.1997.992915.x

127. Nichol JL. Endogenous TPO (eTPO) levels in health and disease: possible clues for therapeutic intervention. Stem Cell. 1998;16 (Suppl 2):165-175. doi:10.1002/stem.5530160719

128. Young NS. Aplastic anemia. $N$ Engl J Med. 2018;379 (17):1643-1656. doi:10.1056/NEJMra1413485

129. Promacta ${ }^{\circledR}$. Eltrombopag. East Hanover, NJ: Novartis Pharmaceuticals Corporation; 2019.

130. Tomiyama Y, Jang JH, Lee J-W, et al. Efficacy and safety of romiplostim in patients with acquired aplastic anemia ineligible or refractory to immunosuppressive therapy: interim analysis of phase 2/3 clinical trial. Blood. 2018;132(Supplement 1):1306. doi:10.1182/blood-2018-99-112478

131. Jang JH, Tomiyama Y, Miyazaki K, et al. Efficacy and safety of romiplostim in refractory aplastic anaemia: a phase II/III, multicentre, open-label study. Br J Haematol. 2021;192(1):190-199. doi:10.1111/bjh.17190

132. ClinicalTrials.gov. Study of AMG531(Romiplostim) in patients with aplastic anemia (NCT03957694). Available from: https://clinicaltrials. gov/ct2/show/NCT03957694. Accessed December 18, 2020.

133. ClinicalTrials.gov. Study of AMG531 (Romiplostim) in patients with aplastic anemia (NCT04095936). Available from: https://clinicaltrials. gov/ct2/show/NCT04095936. Accessed December 18, 2020.

134. Zhao LP, Sicre De Fontbrune F, Contejean A, et al. Nationwide survey in France on the use of romiplostim in patients with refractory severe aplastic anemia. Bone Marrow Transplant. 2019;54(7):1161-1163. doi:10.1038/s41409-019-0452-1

135. Hosokawa K, Yamazaki H, Tanabe M, Imi T, Sugimori N, Nakao S. High-dose romiplostim accelerates hematologic recovery in patients with aplastic anemia refractory to eltrombopag. Leukemia. 2021;35(3):906-909. doi:10.1038/s41375-020-0950-6

136. Ise M, Iizuka $H$, Kamoda $Y$, Hirao M, Kida M, Usuki K. Romiplostim is effective for eltrombopag-refractory aplastic anemia: results of a retrospective study. Int J Hematol. 2020;112 (6):787-794. doi:10.1007/s12185-020-02971-1

137. Alvarado LJ, Andreoni A, Huntsman HD, Cheng H, Knutson JR, Larochelle A. Heterodimerization of TPO and IFN $\gamma$ impairs human hematopoietic stem/progenitor cell signaling and survival in chronic inflammation. Blood. 2017;130(suppl 1):4. doi:10.1182/blood.V130.Suppl_1.4.4

138. Alvarado LJ, Huntsman HD, Cheng H, et al. Eltrombopag maintains human hematopoietic stem and progenitor cells under inflammatory conditions mediated by IFN-gamma. Blood. 2019;133(19):2043-2055. doi:10.1182/blood-2018-11-884486

139. Kim MJ, Park SH, Opella SJ, et al. NMR structural studies of interactions of a small, nonpeptidyl Tpo mimic with the thrombopoietin receptor extracellular juxtamembrane and transmembrane domains. J Biol Chem. 2007;282(19):14253-14261. doi:10.1074/jbc.M611616200

140. Erickson-Miller CL, Delorme E, Tian SS, et al. Preclinical activity of eltrombopag (SB-497115), an oral, nonpeptide thrombopoietin receptor agonist. Stem Cell. 2009;27(2):424-430. doi:10.1634/stemcells.2008-0366

141. Scheinberg P. Stem cell stimulation continues to pay off in aplastic anaemia. Lancet Haematol. 2019;6(11):e543-e544. doi:10.1016/S2352-3026(19)30181-4

142. Bunin DI, Bakke J, Green CE, Javitz HS, Fielden M, Chang PY. Romiplostim (Nplate ${ }^{\circledR}$ ) as an effective radiation countermeasure to improve survival and platelet recovery in mice. Int J Radiat Biol. 2019;96(1):145-154. doi:10.1080/09553002.2019.1605465
143. Yamaguchi M, Hirouchi T, Yokoyama K, Nishiyama A, Murakami S, Kashiwakura I. The thrombopoietin mimetic romiplostim leads to the complete rescue of mice exposed to lethal ionizing radiation. Sci Rep. 2018;8(1):10659. doi:10.1038/ s41598-018-29013-5

144. Yamaguchi M, Hirouchi T, Yoshioka H, Watanabe J, Kashiwakura I. Diverse functions of the thrombopoietin receptor agonist romiplostim rescue individuals exposed to lethal radiation. Free Radic Biol Med. 2019;136:60-75. doi:10.1016/j. freeradbiomed.2019.03.023

145. Hirouchi T, Ito K, Nakano M, et al. Mitigative effects of a combination of multiple pharmaceutical drugs on the survival of mice exposed to lethal ionizing radiation. Curr Pharm Biotechnol. 2015;17 (2):190-199. doi:10.2174/1389201016666150826125331

146. Monzen S, Kimura S, Yamaguchi M, Kashiwakura I. Protective effect of the c-mpl agonist romiplostim on megakaryocytopoiesis of human $\mathrm{CD} 34(+)$ hematopoietic progenitor cells exposed to ionizing radiation. $J$ Interferon Cytokine Res. 2018;38 (5):206-212. doi:10.1089/jir.2017.0104

147. Wong K, Chang PY, Fielden M, et al. Pharmacodynamics of romiplostim alone and in combination with pegfilgrastim on acute radiation-induced thrombocytopenia and neutropenia in non-human primates. Int J Radiat Biol. 2019:1-12. doi:10.1080/ 09553002.2019.1625488

148. Al-Samkari H, Marshall AL, Goodarzi K, Kuter DJ. Romiplostim for the management of perioperative thrombocytopenia. $\mathrm{Br}$ J Haematol. 2018;182(1):106-113. doi:10.1111/bjh.15280

149. Marshall AL, Goodarzi K, Kuter DJ. Romiplostim in the management of the thrombocytopenic surgical patient. Transfusion. 2015;55(10):2505-2510. doi:10.1111/trf.13181

150. Coltoff A, Shreenivas A, Afshar S, Steinberg A. A singleinstitution experience of performing bloodless transplant in Jehovah's witness patients. Hematol Oncol Stem Cell Ther. 2019;12(1):44 49. doi:10.1016/j.hemonc.2018.11.003

151. Moussa MM, Mowafy N. Preoperative use of romiplostim in thrombocytopenic patients with chronic hepatitis $\mathrm{C}$ and liver cirrhosis. Research support, non-U.S. Gov’t. J Gastroenterol Hepatol. 2013;28 (2):335-341. doi:10.1111/j.1440-1746.2012.07246.x

152. Arnold DM, Heddle NM, Cook RJ, et al. Perioperative oral eltrombopag versus intravenous immunoglobulin in patients with immune thrombocytopenia: a non-inferiority, multicentre, randomised trial. Lancet Haematol. 2020;7(9):e640-e648. doi:10.1016/S2352-3026(20)30227-1

153. Bussel JB, Kuter D. Preparing patients with immune thrombocytopenia for surgery: what are the options? Lancet Haematol. 2020;7(9):e626-e627. doi:10.1016/S2352-3026(20)30253-2

154. Pulanic D, Lozier JN, Pavletic SZ. Thrombocytopenia and hemostatic disorders in chronic graft versus host disease. Bone Marrow Transplant. 2009;44(7):393-403. doi:10.1038/bmt.2009.196

155. Nash RA, Gooley T, Davis C, Appelbaum FR. The problem of thrombocytopenia after hematopoietic stem cell transplantation. Oncologist. 1996;1(6):371-380. doi:10.1634/theoncologist.1-6-371

156. Michniacki TF, Ebens CL, Choi SW. Immune-mediated cytopenias after hematopoietic cell transplantation: pathophysiology, clinical manifestations, diagnosis, and treatment strategies. Curr Oncol Rep. 2019;21(10):87. doi:10.1007/s11912-019-0838-7

157. Choi CM, Schmaier AH, Snell MR, Lazarus HM. Thrombotic microangiopathy in haematopoietic stem cell transplantation: diagnosis and treatment. Drugs. 2009;69(2):183-198. doi:10.2165/00003495-200969020-00004

158. Bruno B, Gooley T, Sullivan KM, et al. Secondary failure of platelet recovery after hematopoietic stem cell transplantation. Biol Blood Marrow Transplant. 2001;7(3):154-162. doi:10.1053/bbmt.2001.v7.pm11302549 
159. Bolwell B, Pohlman B, Sobecks R, et al. Prognostic importance of the platelet count 100 days post allogeneic bone marrow transplant. Bone Marrow Transplant. 2004;33(4):419-423. doi:10.1038/sj.bmt.1704330

160. Kuzmina Z, Eder S, Bohm A, et al. Significantly worse survival of patients with NIH-defined chronic graft-versus-host disease and thrombocytopenia or progressive onset type: results of a prospective study. Leukemia. 2012;26(4):746-756. doi:10.1038/leu.2011.257

161. Zaja F, Geromin A, Patriarca F, et al. Prognostic significance of delayed thrombocytopenia after allogeneic stem cell transplant. Am J Hematol. 2011;86(9):790-792. doi:10.1002/ajh.22086

162. Bento L, Bastida JM, Garcia-Cadenas I, et al. Thrombopoietin receptor agonists for severe thrombocytopenia after allogeneic stem cell transplantation: experience of the Spanish Group of hematopoietic stem cell transplant. Biol Blood Marrow Transplant. 2019;25(9):1825-1831. doi:10.1016/j.bbmt.2019.05.023

163. Fominykh M, Voloshin S, Schmidt A, et al. Romiplostim after hematopoietic stem cell transplantation: results of a pilot study. Haematologica. 2012;97:397.

164. Rivera D, Bastida JM, Corral LL, et al. Usefulness of thrombopoietin receptor agonists for thrombocytopenia after allogeneic stem cell transplantation. An eight-year single center experience. Blood. 2017;130(suppl 1):3222.

165. Xue E, Lawrence T, Gernsheimer TB, Milano F. Retrospective evaluation of the use of romiplostim after hematopoietic stem cell transplantation. Blood. 2019;134(suppl 1):5660. doi:10.1182/ blood-2019-128673

166. Poon LM, Di Stasi A, Popat U, Champlin RE, Ciurea SO. Romiplostim for delayed platelet recovery and secondary thrombocytopenia following allogeneic stem cell transplantation. Am J Blood Res. 2013;3(3):260-264.

167. Battipaglia G, Ruggeri A, Brissot E, et al. Safety and feasibility of romiplostim treatment for patients with persistent thrombocytopenia after allogeneic stem cell transplantation. Bone Marrow Transplant. 2015;50(12):1574-1577. doi:10.1038/bmt.2015.182

168. Christakopoulas GE, DeFor TE, Hage SM, et al. Romiplostim improves platelet recovery after UCB transplant [abstract no. 1979]. Blood. 2019;134(Supplement_1):1979. doi:10.1182/ blood-2019-125424

169. Peffault de Latour R, Chevret S, Ruggeri AL, et al. Romiplostim in patients undergoing hematopoietic stem cell transplantation: results of a phase 1/2 multicenter trial. Blood. 2020;135 (3):227-229. doi:10.1182/blood.2019000358

170. Mahat U, Rotz SJ, Hanna R. Use of thrombopoietin receptor agonists in prolonged thrombocytopenia after hematopoietic stem cell transplantation. Biol Blood Marrow Transplant. 2020;26(3):e65-e73. doi:10.1016/j.bbmt.2019.12.003

171. Buchbinder D, Hsieh L, Krance R, Nugent DJ. Successful treatment of post-transplant thrombocytopenia with romiplostim in a pediatric patient with $\mathrm{X}$-linked chronic granulomatous disease. Pediatr Transplant. 2014;18(7):E252-E254. doi:10.1111/ petr. 12325

172. Li S, Wu R, Wang B, et al. Eltrombopag for delayed platelet recovery and secondary thrombocytopenia following allogeneic stem cell transplantation in children. J Pediatr Hematol Oncol. 2019;41(1):38-41. doi:10.1097/MPH.0000000000001263

173. Masetti R, Vendemini F, Quarello P, et al. Eltrombopag for thrombocytopenia following allogeneic hematopoietic stem cell transplantation in children. Pediatr Blood Cancer. 2020;67(5): e28208. doi:10.1002/pbc. 28208

174. Maximova N, Zanon D, Rovere F, Maestro A, Schillani G, Paparazzo R. Romiplostim for secondary thrombocytopenia following allogeneic stem cell transplantation in children. Int $J$ Hematol. 2015;102(5):626-632. doi:10.1007/s12185-0151821-1
175. Ueki H, Igarashi S, Kimura S, et al. Evans syndrome after unrelated bone marrow transplantation for refractory cytopenia of childhood. Pediatr Transplant. 2014;18(7):E246-E251. doi:10.1111/petr.12323

176. Gropper S, Althaus K, Najm J, et al. A patient with Fechtner syndrome successfully treated with romiplostim. Case reports letter. Thromb Haemost. 2012;107(3):590-591. doi:10.1160/ TH11-07-0474

177. Yamanouchi J, Hato T, Kunishima S, Niiya T, Nakamura H, Yasukawa M. A novel MYH9 mutation in a patient with MYH9 disorders and platelet size-specific effect of romiplostim on macrothrombocytopenia. Ann Hematol. 2015;94(9):1599-1600. doi:10.1007/s00277-015-2416-x

178. Pecci A, Ragab I, Bozzi V, et al. Thrombopoietin mutation in congenital amegakaryocytic thrombocytopenia treatable with romiplostim. EMBO Mol Med. 2018;10(1):63-75. doi:10.15252/ emmm.201708168

179. Seo A, Ben-Harosh M, Sirin M, et al. Bone marrow failure unresponsive to bone marrow transplant is caused by mutations in thrombopoietin. Blood. 2017;130(7):875-880. doi:10.1182/ blood-2017-02-768036

180. Pecci A, Gresele P, Klersy C, et al. Eltrombopag for the treatment of the inherited thrombocytopenia deriving from MYH9 mutations. Blood. 2010;116(26):5832-5837. doi:10.1182/blood2010-08-304725

181. Zaninetti C, Gresele P, Bertomoro A, et al. Eltrombopag for the treatment of inherited thrombocytopenias: a Phase II clinical trial. Haematologica. 2020;105(3):820-828. doi:10.3324/haematol.20 19.223966

182. Neunert CE, Rose MJ. Romiplostim for the management of pediatric immune thrombocytopenia: drug development and current practice. Blood Adv. 2019;3(12):1907-1915. doi:10.1182/ bloodadvances.2019000279

183. Van Helmond J, Ganesh J, Ahmed R. Atypical presentation of Wiskott Aldrich syndrome in an infant [abstract]. Pediatr Blood Cancer. 2019;66(S1):S228-S229.

184. Gerrits AJ, Leven EA, Frelinger AL 3rd, et al. Effects of eltrombopag on platelet count and platelet activation in Wiskott-Aldrich syndrome/X-linked thrombocytopenia. Blood. 2015;126(11):1367-1378. doi:10.1182/blood-2014-09602573

185. Dusheiko G. Thrombopoietin agonists for the treatment of thrombocytopenia in liver disease and hepatitis C. Clin Liver Dis. 2009;13(3):487-501. doi:10.1016/j.cld.2009.05.012

186. DOPTELET ${ }^{\circledR}$. Avatrombopag. Durham, NC: AkaRx, Inc.; 2020.

187. MULPLETA ${ }^{\circledR}$. Lusutrombopag Tablets. Florham Park, NJ: Shionogi Inc.; 2020.

188. Castellote J, Girbau A, Arajol C, Xiol X. Romiplostim in chronic liver disease with severe thrombocytopenia undergoing an elective invasive procedure. Case reports letter. Rev Esp Enferm Dig. 2011;103(10):556. doi:10.4321/S1130-01082011001000015

189. Voican CS, Naveau S, Perlemuter G. Successful antiviral therapy for hepatitis $\mathrm{C}$ virus-induced cirrhosis after an increase in the platelet count with romiplostim: two case reports. Eur J Gastroenterol Hepatol. 2012;24(12):1455-1458. doi:10.1097/ MEG.0b013e328357d5f2

190. Steensma DP. Myelodysplastic syndromes: diagnosis and treatment. Mayo Clin Proc. 2015;90(7):969-983. doi:10.1016/j. mayocp.2015.04.001

191. Basood M, Oster HS, Mittelman M. Thrombocytopenia in patients with myelodysplastic syndromes: still an unsolved problem. Mediterr J Hematol Infect Dis. 2018;10(1):e2018046. doi:10.4084/MJHID.2018.046

192. Steensma DP. Myelodysplastic syndromes current treatment algorithm 2018. Blood Cancer J. 2018;8(5):47. doi:10.1038/s41408-018-0085-4 
193. Kantarjian HM, Fenaux P, Sekeres MA, et al. Long-term follow-up for up to 5 years on the risk of leukaemic progression in thrombocytopenic patients with lower-risk myelodysplastic syndromes treated with romiplostim or placebo in a randomised double-blind trial. Lancet Haematol. 2018;5(3):e117-e126. doi:10.1016/S2352-3026(18)30016-4

194. Dodillet H, Kreuzer KA, Monsef I, Skoetz N. Thrombopoietin mimetics for patients with myelodysplastic syndromes. Cochrane Database Syst Rev. 2017;9:CD009883. doi:10.1002/14651858. CD009883.pub2

195. ClinicalTrials.gov. A pilot study of a thrombopoietin-receptor agonist, eltrombopag, in patients with low to int-2 risk myelodysplastic syndrome (MDS) (NCT00961064). Available from: https://clinicaltrials. gov/ct2/show/NCT00961064. Accessed November 10, 2020.

196. ClinicalTrials.gov. Validation of a predictive model of response to romiplostim in patients with IPSS low or intermediate-1 risk MDS and thrombocytopenia (Europe) (NCT02335268). Available from: https://clinicaltrials.gov/ct2/show/ NCT02335268. Accessed November 10, 2020.

197. ClinicalTrials.gov. TPO-mimetic use in children for hemotopoietic failure (NCT04478227). Available from: https:/clinicaltrials. gov/ct2/show/NCT04478227. Accessed November 10, 2020.

198. Greenberg PL, Garcia-Manero G, Moore M, et al. A randomized controlled trial of romiplostim in patients with low- or intermediate-risk myelodysplastic syndrome receiving decitabine. Research support, non-U.S. Gov't. Leuk Lymphoma. 2013;54(2):321-328. doi:10.3109/10428194.2012.713477
199. Giagounidis A, Mufti GJ, Fenaux P, et al. Results of a randomized, double-blind study of romiplostim versus placebo in patients with low/intermediate-1-risk myelodysplastic syndrome and thrombocytopenia. Cancer. 2014;120(12):1838-1846. doi:10.1002/cncr.28663

200. Bussel JB, Kuter DJ, Aledort LM, et al. A randomized trial of avatrombopag, an investigational thrombopoietin-receptor agonist, in persistent and chronic immune thrombocytopenia. Blood. 2014;123(25):3887-3894. doi:10.1182/blood-2013-07-514398

201. Kuter DJ, Tarantino MD, Lawrence T. Clinical overview and practical considerations for optimizing romiplostim therapy in patients with immune thrombocytopenia. Blood Rev. 2021;100811. doi:10.1016/j.blre.2021.100811

202. Janssens A, Tarantino M, Bird RJ, et al. Romiplostim treatment in adults with immune thrombocytopenia of varying duration and severity. Acta Haematol. 2015;134(4):215-228. doi:10.1159/ 000381657

\section{Publish your work in this journal}

Drug Design, Development and Therapy is an international, peerreviewed open-access journal that spans the spectrum of drug design and development through to clinical applications. Clinical outcomes, patient safety, and programs for the development and effective, safe, and sustained use of medicines are a feature of the journal, which has also been accepted for indexing on PubMed Central. The manuscript management system is completely online and includes a very quick and fair peer-review system, which is all easy to use. Visit http://www. dovepress.com/testimonials.php to read real quotes from published authors. 